\title{
Iceland: Improving the Equity and Revenue Productivity of the Icelandic Tax System
}

This report on "Improving the Equity and Revenue Productivity of the Icelandic Tax System" for the country of Iceland was prepared by a staff team of the International Monetary Fund. It is based on the information available at the time it was completed in June 2010. The views expressed in this document are those of the staff team and do not necessarily reflect the views of the government of Iceland or the Executive Board of the IMF.

Copies of this report are available to the public from

International Monetary Fund • Publication Services $70019^{\text {th }}$ Street, N.W. • Washington, D.C. 20431

Telephone: (202) 623-7430 • Telefax: (202) 623-7201

E-mail: publications@imf.org Internet: http://www.imf.org

\section{International Monetary Fund Washington, D.C.}




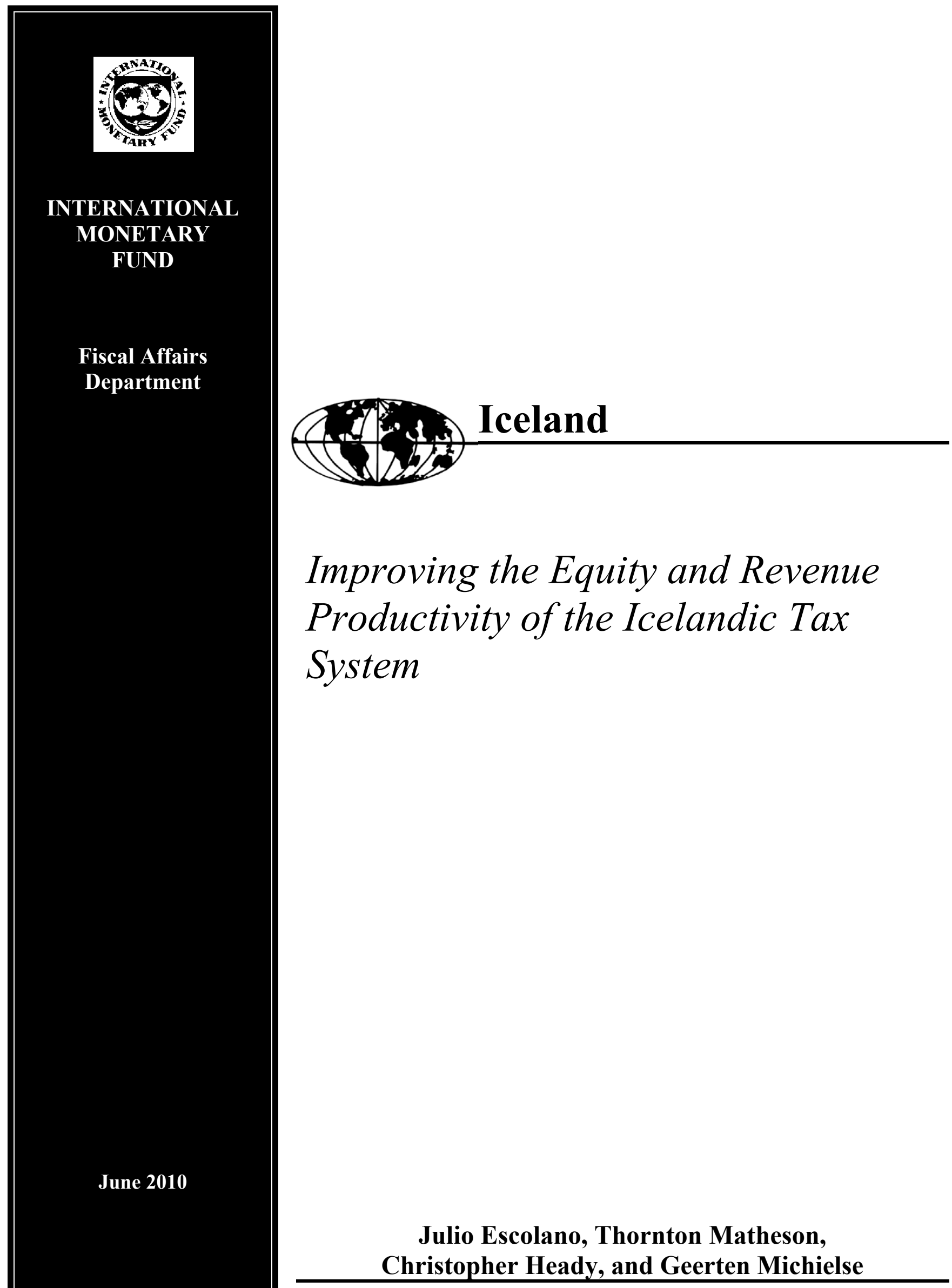

For Official Use Only 



\section{INTERNATIONAL MONETARY FUND}

Fiscal Affairs Department

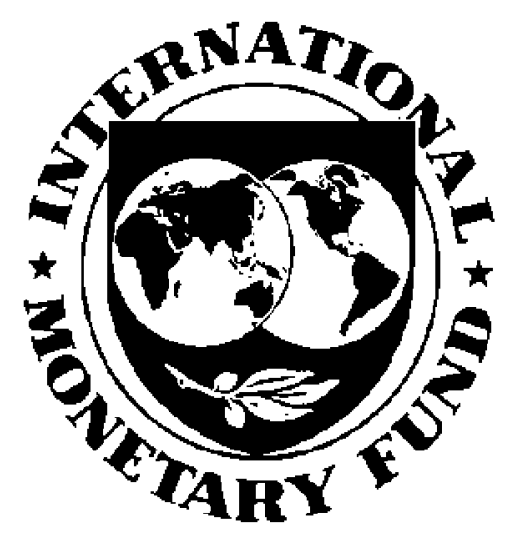

\section{ICELAND}

\section{Improving The EQuity ANd Revenue Productivity OF THE ICELANDIC TAX SYSTEM}

Julio Escolano, Thornton Matheson, Christopher Heady, and Geerten Michielse June 2010 
The contents of this report constitute technical advice provided by the staff of the International Monetary Fund (IMF) to the authorities of Iceland (the "TA recipient") in response to their request for technical assistance. This report (in whole or in part) or summaries thereof may be disclosed by the IMF to IMF Executive Directors and members of their staff, as well as to other agencies or instrumentalities of the TA recipient, and upon their request, to World Bank staff and other technical assistance providers and donors with legitimate interest, unless the TA recipient specifically objects to such disclosure (see Operational Guidelines for the Dissemination of Technical Assistance Information-

http://www.imf.org/external/np/pp/eng/2009/040609.pdf).

Disclosure of this report (in whole or in part) or summaries thereof to parties outside the IMF other than agencies or instrumentalities of the TA recipient, World Bank staff, other technical assistance providers and donors with legitimate interest shall require the explicit consent of the TA recipient and the IMF's Fiscal Affairs Department. 


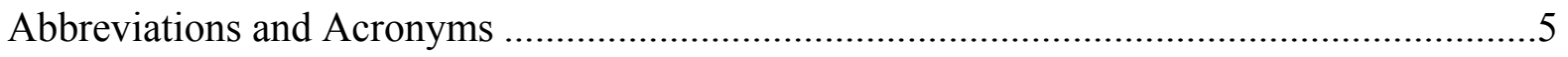

Preface

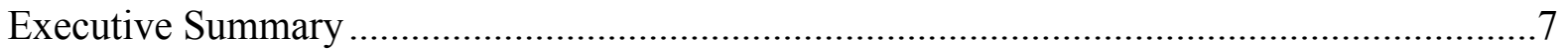

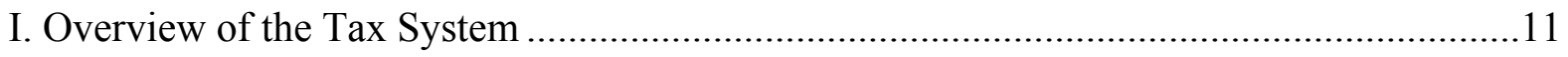

A. Tax Levels and Tax Structures in a Regional Context...........................................11

B. The Efficiency of the Tax System..................................................................13

C. Fairness in the Tax System...........................................................................15

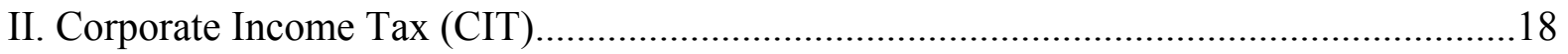

A. Financial Versus Tax Accounting ......................................................................19

B. Capital Losses and Debt Forgiveness.....................................................................19

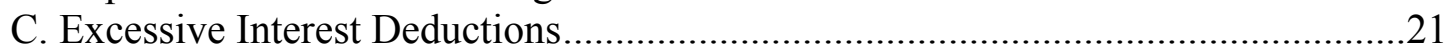

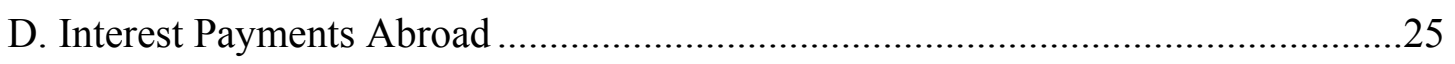

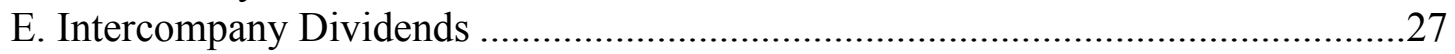

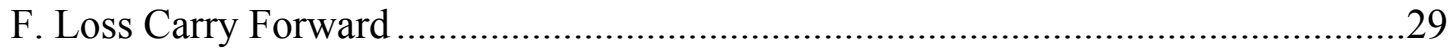

G. Investment Incentives ..............................................................................

III. Personal Income Tax (PIT) and Direct Taxes on Individuals...........................................30

A. Allocating Labor and Capital Income within Closely Held Businesses ...................30

B. Increasing Revenue and Progressivity .......................................................................33

IV. Capital Income Taxation and Corporate Integration ........................................................38

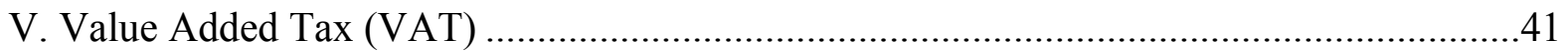

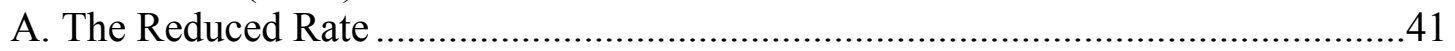

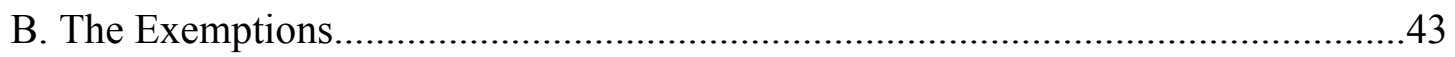

C. Unrecoverable Input VAT............................................................................. 44

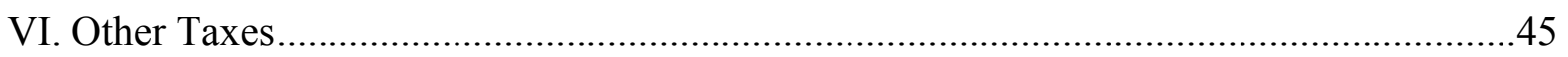

A. Recurrent Taxes on Immovable Property ………………...................................45

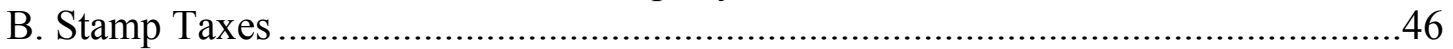

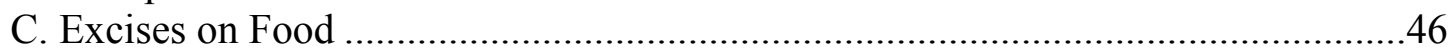

D. Excises on Alcohol, Fuel and Tobacco ………………......................................47

E. Taxes on Motor Vehicles.............................................................................49

F. Resource and Environmental Taxes ....................................................................49 
Tables

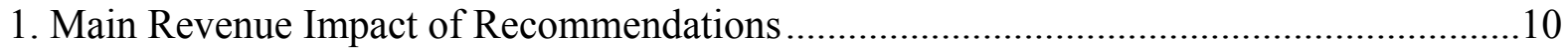

2. Ratios of Tax to GDP for Selected Countries, 2007 .....................................................12

3. VAT Rates in Selected Countries ................................................................................... 14

4. The Redistribution Produced by Taxes and Transfers ...................................................17

5. Thin Capitalization Rules ...........................................................................................2 23

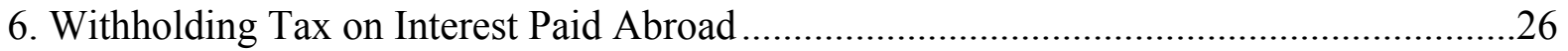

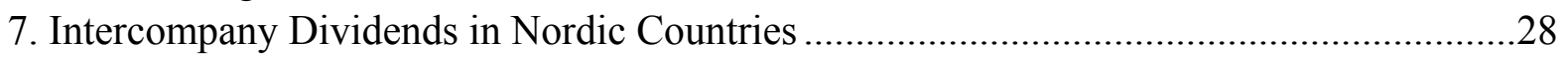

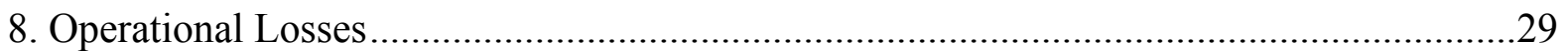

9. Methods for Allocating Business Income Between Capital and Labor ..............................32

10. Comparison of Nordic Dual Income Tax Systems ........................................................36

11. Revenue and Price Effects of VAT Reforms ........................................................42

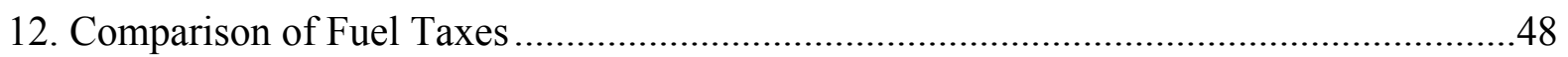

Figures

1. Reduction in Inequality Due to Public Cash Transfers and Household Taxes ...................18

Appendix

Summary of Recommendations ................................................................................. 51 


\section{AbBreviations AND ACRONYMS}

ACE Allowance for corporate equity

CIT Corporate income tax

CPI Consumer price index

EBIT Earnings before interest (paid) and taxes

EBITDA Earnings before interest (paid), taxes, depreciation, and amortization

EEA European Economic Area

ETS Emissions Trading System

EU European Union

EU15 First 15 members of the EU: Austria, Belgium, Denmark, Finland, France, Germany, Greece, Ireland, Italy, Luxembourg, Netherlands, Portugal, Spain, Sweden, and the United Kingdom

EUR Euro (or when plural, euros)

FDI Foreign direct investment

GDP Gross domestic product

IFRS International Financial Reporting Standards

ISK Icelandic króna (or when plural, Icelandic krónur)

ITA Income Tax Act (in graphs or tables, ITA stands for Italy)

OECD Organization for Economic Co-operation and Development

OECD-24 First 24 members of the OECD: Austria, Australia, Belgium, Canada, Denmark, Finland, France, Germany, Greece, Iceland, Ireland, Italy, Japan, Luxembourg, Netherlands, New Zealand, Norway, Portugal, Spain, Sweden, Switzerland, Turkey, United Kingdom, and the United States

PAYE Pay-as-you-go

PIT Personal income tax

US\$ US dollar (or when plural, US dollars)

VAT Value added tax 


\section{Preface}

In response to a request from the Icelandic authorities to conduct a review of their system of taxes, a mission from the Fiscal Affairs Department of the International Monetary Fund visited Reykjavik during April 26-May 7, 2010. This report presents the mission's findings and recommendations.

The mission comprised Julio Escolano (head), Thornton Matheson (both FAD), Professor Christopher Heady and Professor Geerten M. M. Michielse (both members of the IMF panel of fiscal experts). Mr. Franek Rozwadowski (IMF Resident Representative) and Ms. Edda Rós Karlsdóttir (IMF Resident Representative's office) participated in the meetings.

The mission held discussions with Mr. Steingrímur J. Sigfússon, Minister of Finance, Mr. Guðmundur Árnason, Permanent Secretary, Mr. Indriði H. Porláksson, Special Adviser to the Minister, Ms. Maríanna Jónasdóttir, Director-General (Department of Revenue and Taxation), Mr. Sigurður Guðmundsson, Head of Division (Department of Revenue and Taxation) and their staff. The mission also held discussions with officials from the Internal Revenue Directorate, the Tax Investigations Directorate, the Ministry of Industry, and Statistics Iceland. The mission benefited from discussions with representatives of labor and employer unions and social partners, the private sector, tax professionals and academics, and the Icelandic Association of Local Authorities.

The mission would like to express its gratitude to the Icelandic authorities for the assistance and the cooperation it received. 


\section{EXECUTIVE SUMMARY}

The Icelandic authorities have launched a review of the tax system with a view to improving its income redistribution, growth orientation, and efficiency features, as well as increasing its revenue mobilization potential by 1-2 percentage points of GDP over the medium term. The increased tax collections would shore up the public finances in the wake of the recent crisis and fund medium-term policies to strengthen income redistribution, the social safety net, and public service provision, which are seen as lagging relative to other Nordic countries.

The Icelandic tax system already embodies in many of its features the state of the art in tax policy. It is reasonably simple with relatively low rates, broad tax bases, and few special favorable treatments and opportunities for tax arbitrage or avoidance. As a consequence, it collects a comparatively large amount of revenue while minimizing adverse effects on employment, economic activity, and compliance costs. Indeed, based on the OECD Revenue Statistics, Iceland has had a high revenue ratio in comparison with other OECD countries, and even among other Nordic countries. ${ }^{1}$

The recommendations that follow build on these strengths rather than taking the route of a radical departure from the current tax structure. They aim at minimizing detrimental effects on employment and growth, and at removing inconsistencies with international practices. The suggested tax measures - some with compensating transfers to low-income individuals - would boost the revenue potential in line with the authorities' objectives (Table 1), while substantially increasing income redistribution. The attendant increase in tax yield could support the budget or be used to reduce some of the general tax rates in a net revenue-neutral manner. The impact estimations here are preliminary. Eventual tax measures should be accompanied by an objective technical assessment based on official statistical data regarding their effects on economic activity and income redistribution, as is common practice in many OECD countries. Broad consultation with social partners and civil society should not be seen as a substitute for this analysis.

Fairness. The report analyzes the structure of the Icelandic tax system in the context of other Nordic, European and OECD countries. It emerges that countries that achieve the highest redistribution through their tax and benefit systems do so consistently through the spending side of the budget. In contrast, progressivity of the tax system appears low in all countries and bears little relation with the overall reduction in inequality through public policies. Success in the latter objective appears linked to strong benefit systems funded by tax systems

\footnotetext{
${ }^{1}$ When the compulsory pension contributions are included for Iceland, or when social security taxes are excluded for all countries. Most compulsory pension contributions in Iceland are paid into private pension funds and thus do not score as taxes. In contrast, for example, Denmark funds the bulk of pension payments from general taxes, which requires a higher non-social security tax ratio than otherwise.
} 
able to collect significant revenue. Taking tax progressivity beyond a certain point erodes revenue productivity due to associated economic distortions, footloose tax bases, and opportunities for tax avoidance. This, in turn, undermines the government's ability to undertake effective redistributive policies. In conclusion, the key contribution of the Icelandic tax system to the government objectives of income redistribution needs to be raising revenue efficiently in the necessary amounts, rather than achieving the desired reduction in inequality on its own. That said, the recommendations that follow aim at increasing the progressivity of the Icelandic tax system where opportunities exist.

CIT. While already consistent with OECD country practices, the Icelandic CIT would benefit from adopting financial accounting (IFRS in Iceland) as the basis to determine taxable income, except when explicitly otherwise indicated in the Income Tax Act. In particular, capital gains and losses should be treated as regular income. This would address many of the current difficulties in dealing with derivatives and other complex operations, and with debt forgiveness. Legacy cases in the latter area associated with the recent crisis could be dealt through a one-time transition policy. The current general arm's length criterion appears insufficient to forestall excessive interest expensing and could be complemented by a thin capitalization test, and treaty-based withholding relief on interest payments abroad expedited. Changes to the treatment of intercompany dividends would improve consistency with EU practices. Investment incentives under consideration could severely threaten the tax base-it is essential to avoid tax concessions or, at a minimum, radically restrict eligibility.

PIT. The current Icelandic taxation of individual capital income at a uniform rate separately from labor income and other earnings (the "dual income tax") allows capturing a broad base by offering little opportunity for tax arbitrage and very few exemptions - thus maximizing the effective revenue potential of this highly mobile base. The dual income tax is a feature of all Nordic tax systems (except Denmark) and lower taxes on capital income are applied in most OECD countries. Switching to comprehensive taxation with the progressive rate schedule applied to capital income is not advisable as it would severely harm savings, investment and job creation. In practice, it would likely result in complex exemptions, deductions, and special treatments, and ultimately erode revenue. The relatively favorable treatment of capital income, however, appears to have prompted a multiplication of closely held corporations to shelter income from the progressive taxation of labor income. It is recommended that closely held corporation and partnership income be split by determining capital income by a normal return on assets (e.g., the rate on medium-term government bonds) after deducting interest paid; the rest would be treated as labor income.

The PIT rate schedule has a comparatively large tax credit and consequently a steep jump at the first non-zero rate, while the first and last non-zero tax brackets are very narrow. To increase progressivity and revenue, and given the difficulties in reducing the tax credit, it is recommended that the non-zero brackets be reduced to two with the threshold between them at ISK 4.5 million and rates of 37.2 percent (the current first rate) and 47.2 percent. This 
would yield about 0.25 percentage point of GDP in additional revenue. An alternative is also suggested, which would raise more revenue ( 0.4 percent of GDP) and keep three brackets, but it would entail a lower increase in progressivity. Raising the current 18 percent rates on corporate and individual capital income (which are lower than in other Nordic countries) to 20 percent would raise over 0.3 percent of GDP in additional revenue. It would also bring the consolidated tax rate on distributed profits very close to the lowest non-zero marginal rate on labor income, reducing tax arbitrage possibilities. In order to better integrate the corporate and individual taxation of capital income, and drastically reduce incentives for thin capitalization, it is recommended that the authorities consider for the medium term the introduction of a modified Allowance for Corporate Equity (ACE) in the CIT. This would allow the deduction of a normal return on assets and tax only profits and interest paid in excess of the normal return. However, the cross-border implications of a modified ACE warrants further study, and it is not recommended until budgetary pressures subside, owing to a likely revenue loss.

VAT. Compared to other OECD countries, the Icelandic VAT levies a large amount of revenue with low adverse effects on employment and growth. Non-standard exemptions and a lower second rate, however, undermine its neutrality and revenue potential without achieving any redistributive goals given Icelandic household expenditure patterns. It is recommended that, as circumstances permit, these features be removed in conjunction with the allocation of about one third of the revenue gain to fully compensate poorer households through means-tested programs. This would increase revenue by $1 \frac{1}{2}$ percentage points of GDP net of compensation costs and greatly increase overall progressivity. A more modest reform is also proposed as an intermediate step: eliminating non-standard exemptions and bringing the lower 7 percent rate back to 14 percent while restricting it to food, with full compensation to low-income households. This would yield slightly more than 1 percent of GDP net of compensation costs and would also increase the progressivity of the overall system, albeit to a lesser extent. In addition, better targeting of the local government refund for unrelieved VAT credit would increase efficiency.

Other taxes. The report welcomes the introduction of resource and environmental taxes, while pointing to potential base broadening and rate increases toward EU Emission Trading System (ETS) prices. Raising fuel tax rates (with compensating public transportation subsidies) would yield 0.3 percent of GDP. Food excises should be better targeted or otherwise phased out over time. Stamp duties should also be phased out due to their distortive and unfair features. The neutrality of motor vehicle taxes and associated incentives to fuel efficiency could be enhanced. Finally, property taxes offer significant revenue-raising potential with little negative implication for economic activity—which could be considered as incomes and housing markets recover. 


\section{Table 1. Main Revenue Impact of Recommendations}

(Net revenue in percent of GDP)

\begin{tabular}{|c|c|c|}
\hline Recommendation & Basic measures & $\begin{array}{c}\text { Alternative } \\
\text { measures }\end{array}$ \\
\hline $\begin{array}{l}\text { Raising the reduced VAT rate to } 14 \text { percent, limiting } \\
\text { reduced rate to food and eliminating non-standard } \\
\text { exemptions, while compensating low income households. }\end{array}$ & 1.1 & \\
\hline $\begin{array}{l}\text { Eliminating reduced rate for VAT and non-standard } \\
\text { exemptions, while compensating low income households }\end{array}$ & & 1.5 \\
\hline $\begin{array}{l}\text { Increasing the fuel excise half way to Norwegian levels, } \\
\text { while compensating public transport }\end{array}$ & 0.25 & \\
\hline $\begin{array}{l}\text { Improving the progressivity of the personal income tax by } \\
\text { moving to a two-bracket system }\end{array}$ & 0.25 & \\
\hline $\begin{array}{l}\text { Improving the progressivity of the personal income tax by } \\
\text { restructuring the three-bracket system }\end{array}$ & & 0.43 \\
\hline $\begin{array}{l}\text { Increasing the personal capital income tax rate to } \\
20 \text { percent }\end{array}$ & 0.3 & \\
\hline Increasing the corporate tax rate to 20 percent & 0.13 & \\
\hline Total revenue & 2.03 & \\
\hline
\end{tabular}

Note: The revenues presented here for the VAT and fuel excise reform are net of proposed compensation measures for low-income groups. 


\section{OVERVIEW OF THE TAX SYSTEM}

\section{A. Tax Levels and Tax Structures in a Regional Context}

\section{Tax level}

1. International comparisons of tax levels across countries are never perfect, but the comparison of Iceland with other Nordic and OECD countries is particularly difficult. This is because, in contrast to most OECD countries, compulsory pension contributions are made to institutions outside government - and thus, appropriately, they are not counted as taxes. This fact is reflected in Iceland's comparatively low government revenue from social security contributions. One way to circumvent this difficulty is to compare tax levels that exclude social security contributions in Iceland and in other countries. Alternatively, Iceland's tax revenue can be augmented with the compulsory contributions paid into pension funds, and the resulting level compared with the tax levels of other countries (this time including social security contributions). Both methods point to a similar conclusion: Iceland's tax level as a proportion of GDP is among the highest in the OECD.

2. In 2007, the last year for which full comparative tax revenue data are available and the year before the crisis, Iceland had tax revenue (excluding social security contributions) of 37.7 percent of GDP. ${ }^{2}$ This was the second highest tax ratio (excluding social security contributions) in the OECD, behind Denmark (47.7 percent), and well above both the average EU15 ratio (28.7 percent) and the average OECD ratio (26.7 percent). It was also generally above the ratio of other Nordic OECD countries, where the ratio ranged from 31.1 percent in Finland to 35.7 percent in Sweden (Table 2). However, this approach is not perfect because some countries finance pensions from general taxation rather than social security contributions, and Denmark is an example of this practice. Perhaps a better way to achieve a rough comparability is to add the compulsory pension contributions (99 billion ISK in 2007, which was about 7.6 percent of GDP) to Iceland's tax revenue, which produces a total ratio of 48.5 percent, only slightly below Denmark - the country with the highest tax ratio in the OECD (now including social security contributions for both countries).

3. This position of Iceland as a comparatively heavily taxed country comes out clearly when looking at the taxes levied on specific tax bases (excluding, of course, social security contributions) and implies that considerable care needs to be taken to ensure that any additional revenues are collected in the most efficient manner in order to avoid serious harm to the economy. Table 2 shows that the Icelandic ratio of income tax revenue (personal plus corporate) to GDP was 18.5 percent, which is within the Nordic range (16.9 percent to 29.0 percent) but well above the EU15 and OECD averages (14.0 percent and 13.2 percent).

\footnotetext{
${ }^{2}$ Notice, however, that 2007 was a year of particularly high tax revenue in Iceland, as the booming economic activity boosted consumption and other tax bases.
} 
In addition, Iceland's revenue from consumption taxes was a higher proportion of GDP (16.5 percent) than any other Nordic country and was among the very highest for the OECD as a whole. ${ }^{3}$ This was due to both high VAT collections, which were the highest share of GDP in the OECD, and high levels of excise taxes. On a much smaller scale, it was also above other Nordic countries and the EU15 and OECD averages for the ratio of property taxes to GDP.

Table 2. Ratios of Tax to GDP for Selected Countries, 2007

(In percent of)

\begin{tabular}{cccccccc}
\hline & Iceland & Denmark & Finland & Norway & Sweden & $\begin{array}{c}\text { EU 15 } \\
\text { average }\end{array}$ & $\begin{array}{c}\text { OECD } \\
\text { average }\end{array}$ \\
\hline $\begin{array}{c}\text { Total tax } \\
\text { excluding social } \\
\text { security }\end{array}$ & 37.7 & 47.7 & 31.1 & 34.6 & 35.7 & 28.7 & 26.7 \\
Income taxes & 18.5 & 29.0 & 16.9 & 21.0 & 18.7 & 14.0 & 13.2 \\
Payroll taxes & 0.0 & 0.2 & 0.0 & 0.0 & 2.7 & 14.0 & 13.2 \\
$\begin{array}{c}\text { Property taxes } \\
\text { Consumption } \\
\text { taxes }\end{array}$ & 2.5 & 1.9 & 1.1 & 1.2 & 1.2 & 2.1 & 1.9 \\
$\begin{array}{c}\text { Other taxes } \\
\begin{array}{c}\text { Social security } \\
\text { contributions }\end{array}\end{array}$ & 0.1 & 0.0 & 0.0 & 0.0 & 0.1 & 0.3 & 0.2 \\
$\begin{array}{c}\text { Total tax } \\
\text { including social } \\
\text { security 1/ }\end{array}$ & 40.9 & 16.3 & 12.9 & 12.4 & 12.9 & 11.6 & 10.9 \\
\hline
\end{tabular}

Source: OECD, Revenue Statistics, 1965-2008, C 2009.

1/ This line does not include compulsory contributions to non-government (i.e., private) pension funds, since they are not taxes. In Iceland, these compulsory contributions to private pension funds amounted to 7.6 percent of GDP in 2007.

\footnotetext{
${ }^{3}$ Iceland's consumption tax revenues are unusually volatile, reflecting the volatility of private consumption that is noted in the Central Bank of Iceland's Monetary Bulletin 2010-12, Box IV-1, pp. 44-48. Their ratio to GDP can vary by as much as 3 percentage points over the economic cycle.
} 


\section{Tax rates}

4. In common with Finland, Norway and Sweden, Iceland has a dual income tax system for personal incomes in which capital income is taxed at a flat rate that is lower than the (usually) progressive rates on labor income. Iceland's taxation of labor income was also based on a flat rate for a short period before the financial crisis, after which one and then another additional tax bracket were added. Progressivity of the earlier flat rate tax on labor income was achieved by a substantial personal tax credit.

5. The flat tax on capital income was 10 percent until the middle of 2009 , when it was raised to 15 percent and then to 18 percent in 2010. This rate is low in comparison both to other Nordic countries and to the lowest Iceland rate on labor income. This low rate can partly be explained by the fact that, in contrast to other Nordic countries, there is no general deduction for interest paid (although there is a tax credit related to mortgage interest). Dividends are taxed at the same rate as interest and capital gains. The corporate tax rate was 15 percent in 2009 and was raised to 18 percent in 2010.

6. The main rate of value added tax (VAT) is 25.5 percent, recently raised from 24.5 percent, and is the highest rate in the OECD. There is also a lower rate of VAT of 7 percent on food and a number of other items. Table 3 provides a comparison of Iceland's VAT rates with other selected countries in recent years. It is particularly interesting that Denmark has a VAT rate similar to Iceland's but has no reduced rate. The excise duties on alcohol and tobacco are high by international standards, as is standard for Nordic countries, but the excise taxes on motor fuel are low by Nordic standards. There is also a relatively high excise duty on vehicle import. Like some other Nordic countries, there are also excises on selected food items.

7. The rate of recurrent taxation on residential property is set by municipalities but is typically close to the maximum 0.5 percent of market value, with other rates applying to other types of property including agricultural land. A new net wealth tax has recently been introduced with a rate of 1.25 percent that applies above the thresholds of 90 million ISK (single individual) or 120 million ISK (couples). There is also an inheritance tax of 5 percent with a threshold of one million ISK.

\section{B. The Efficiency of the Tax System}

\section{Tax mix}

8. In many respects, the tax mix in Iceland is consistent with the promotion of economic growth. It is generally accepted that income taxes (particularly corporate income taxes) are the most harmful for job creation, investment, and growth while consumption taxes and recurrent taxes on immovable property are the least harmful. Thus, compared to other Nordic countries, the relatively low share of income taxes and social security contributions (which 
have much the same effect on growth as income taxes) and the relatively high share of consumption taxes in Iceland can be expected to be good for growth.

Table 3. VAT Rates in Selected Countries

\begin{tabular}{|l|r|r|r|r|r|r|r|r|r|r|r|r|r|}
\hline & \multicolumn{9}{|c|}{ Standard Rates } & & & \multicolumn{2}{|c|}{$\begin{array}{c}\text { Reduced Domestic } \\
\text { Rates }\end{array}$} \\
\hline & $\mathbf{2 0 0 0}$ & $\mathbf{2 0 0 1}$ & $\mathbf{2 0 0 2}$ & $\mathbf{2 0 0 3}$ & $\mathbf{2 0 0 4}$ & $\mathbf{2 0 0 5}$ & $\mathbf{2 0 0 6}$ & $\mathbf{2 0 0 7}$ & $\mathbf{2 0 0 8}$ & $\mathbf{2 0 0 9}$ & & zero rate \\
\hline Austria & 20.0 & 20.0 & 20.0 & 20.0 & 20.0 & 20.0 & 20.0 & 20.0 & 20.0 & 20.0 & $10.0 / 12.0$ & no \\
\hline Belgium & 21.0 & 21.0 & 21.0 & 21.0 & 21.0 & 21.0 & 21.0 & 21.0 & 21.0 & 21.0 & $6.0 / 12.0$ & yes \\
\hline Denmark & 25.0 & 25.0 & 25.0 & 25.0 & 25.0 & 25.0 & 25.0 & 25.0 & 25.0 & 25.0 & - & yes \\
\hline Finland & 22.0 & 22.0 & 22.0 & 22.0 & 22.0 & 22.0 & 22.0 & 22.0 & 22.0 & 22.0 & $8.0 / 17.0$ & yes \\
\hline France & 20.6 & 19.6 & 19.6 & 19.6 & 19.6 & 19.6 & 19.6 & 19.6 & 19.6 & 19.6 & $2.1 / 5.5$ & no \\
\hline Germany & 16.0 & 16.0 & 16.0 & 16.0 & 16.0 & 16.0 & 16.0 & 19.0 & 19.0 & 19.0 & 7.0 & no \\
\hline Iceland & 24.5 & 24.5 & 24.5 & 24.5 & 24.5 & 24.5 & 24.5 & 24.5 & 24.5 & 24.5 & 7.0 & yes \\
\hline Ireland & 21.0 & 21.0 & 21.0 & 21.0 & 21.0 & 21.0 & 21.0 & 21.0 & 21.0 & 21.5 & $4.8 / 13.5$ & yes \\
\hline Italy & 20.0 & 20.0 & 20.0 & 20.0 & 20.0 & 20.0 & 20.0 & 20.0 & 20.0 & 20.0 & $4.0 / 10.0$ & yes \\
\hline Luxembourg & 15.0 & 15.0 & 15.0 & 15.0 & 15.0 & 15.0 & 15.0 & 15.0 & 15.0 & 15.0 & $3.0 / 6.0 / 12.0$ & no \\
\hline Netherlands & 17.5 & 19.0 & 19.0 & 19.0 & 19.0 & 19.0 & 19.0 & 19.0 & 19.0 & 19.0 & 6.0 & no \\
\hline Norway & 23.0 & 24.0 & 24.0 & 24.0 & 24.0 & 25.0 & 25.0 & 25.0 & 25.0 & 25.0 & $8.0 / 14.0$ & yes \\
\hline Poland & 22.0 & 22.0 & 22.0 & 22.0 & 22.0 & 22.0 & 22.0 & 22.0 & 22.0 & 22.0 & 7.0 & yes \\
\hline Portugal & 17.0 & 17.0 & 17.0 & 19.0 & 19.0 & 19.0 & 21.0 & 21.0 & 21.0 & 21.0 & $5.0 / 12.0$ & no \\
\hline Spain & 16.0 & 16.0 & 16.0 & 16.0 & 16.0 & 16.0 & 16.0 & 16.0 & 16.0 & 16.0 & $4.0 / 7.0$ & no \\
\hline Sweden & 25.0 & 25.0 & 25.0 & 25.0 & 25.0 & 25.0 & 25.0 & 25.0 & 25.0 & 25.0 & $6.0 / 12.0$ & yes \\
\hline Switzerland & 7.5 & 7.6 & 7.6 & 7.6 & 7.6 & 7.6 & 7.6 & 7.6 & 7.6 & 7.6 & $2.4 / 3.6$ & yes \\
\hline United Kingdom & 17.5 & 17.5 & 17.5 & 17.5 & 17.5 & 17.5 & 17.5 & 17.5 & 17.5 & 15.0 & 5.0 & yes \\
\hline & & & & & & & & & \\
\hline
\end{tabular}

Source: OECD, Tax Database, (C) 2010.

9. It could be argued that the share of consumption taxes could still be increased. However, the standard rate of VAT is already the highest in the OECD and tax fraud and evasion could increase significantly if it were increased further. This suggests that the only consumption items that should be considered for additional taxation are those that are comparatively lightly taxed: the goods that are subject to the 7 percent VAT rate or exempted from VAT, vehicle fuels and natural resources (such as geothermal energy). An additional problem with increasing consumption taxes in Iceland is that long-term loans, such as housing finance, are generally indexed to the consumer price index. This means that any inflationary effect of consumption tax increases would increase the servicing burden of debtors, including those with mortgages. 
10. In addition, the fairly high tax revenues from residential property taxes are less harmful to growth. Here, there is a stronger argument for increasing the tax. This is because Iceland is a small country with mobile capital and labor, which could migrate in response to tax increases. This makes the taxation of immovable property attractive from an efficiency point of view. It is worth noting that countries such as Canada, the UK and the US have considerably higher rates of residential property taxes.

\section{Simplicity and stability}

11. Iceland's tax system is very streamlined by OECD standards. There are minimal deductions from the labor income tax base, virtually none from the capital income tax base, ${ }^{4}$ and few special exemptions under the corporate tax. Even with the recent added complexity of the two additional income tax brackets and the introduction of a net wealth tax, the system fits very well with the ideal of 'low rates and broad base' - a feature that explains to a large extent its high revenue productivity.

12. The most obvious area in which the effective base could be expanded would be by limiting the goods included in the reduced VAT band and raising that rate. In addition, that would clearly reduce complexity.

13. The more serious difficulties that businesses are experiencing with the tax system have to do with two aspects of the tax law. The first is that much of it is rather old and does not provide clear enough rules for the taxation of new arrangements, such as derivatives and other complex operations. The second is that the changes in the tax law at the end of 2009 that were designed to meet the pressing need for additional tax revenue have produced considerable surprises and complaints that the new provisions are not drafted with sufficient detail.

14. This is clearly related to the issue of stability, which is generally regarded as an important criterion for a good tax system. Tax systems do have to change with economic circumstances, but it is best if the changes can be announced well in advance and if there can be adequate time for consultation on the legislative drafting.

\section{Fairness in the Tax System}

15. Fairness is generally regarded as a crucial element of any tax system. However, the progressivity of the tax system should be seen as a whole rather than requiring each individual tax to be progressive. It is common to find a tax system with considerable overall progression that contains some taxes that are regressive. Typically, the progressivity of the

\footnotetext{
${ }^{4}$ Interest income has an exemption of ISK 100,000; and only 70 percent of rental income is subject to tax (in lieu of itemized deductions, which are not provided).
} 
labor income tax can compensate for the inequalities in other taxes that are required for efficiency reasons.

16. More generally, government policies achieve redistribution of income through both the tax system and the social benefit system. The redistribution that is achieved in selected OECD countries is shown in Table 4. This shows that, before the application of taxes and benefits, Iceland's inequality is very low in comparison to other countries, including other Nordic countries. However, its tax and benefit system does not achieve as much redistribution as other Nordic countries, and so the income inequality after taxes and benefits is at the high end of the range of Nordic countries, although still below the OECD average.

17. However, increasing the overall redistribution does not mean that Iceland's taxes need to be made substantially more progressive. Figure 1 (for which Icelandic data were not available ${ }^{5}$ ) shows that other Nordic countries have put more of the responsibility for redistribution on the benefit system and have chosen to finance the large public expenditures required by efficient but not particularly redistributive taxes.

18. Indeed, Figure 1 shows that the extent of redistribution across countries is closely associated to the redistribution achieved through the benefit system, while tax progressivity is relatively uncorrelated with overall redistribution through public policies. Effective redistribution through the benefit system, in turn, typically requires relatively high tax collections which results in tax systems geared towards revenue productivity rather than redistribution. This is partly because attempts to make the tax system progressive beyond a point erodes its revenue productivity and ultimately undermines the redistributive effectiveness of the overall public system. For example, Sweden achieves the highest percentage reduction of the Gini coefficient among all OECD countries (46 percent). However, the redistribution achieved through the Swedish tax system is below the OECD average. In contrast, the tax system of the United States is among the most redistributive, but the overall redistribution achieved through the combined effect of taxes and benefit policies is the second lowest in the OECD sample. In conclusion, the key role for Iceland's tax system in reducing inequality is to provide an efficient means of raising revenue to finance social benefits, rather than achieving a great deal of redistribution itself.

\footnotetext{
${ }^{5}$ The authorities have started the process of collecting the necessary data and of estimating the redistributive impact of the tax and benefit systems separately.
} 
Table 4. The Redistribution Produced by Taxes and Transfers

\begin{tabular}{|c|c|c|c|c|}
\hline & & & Inequal & reduction \\
\hline & $\begin{array}{c}\text { Gini after taxes and } \\
\text { transfers }\end{array}$ & $\begin{array}{c}\text { Gini before taxes and } \\
\text { transfers }\end{array}$ & $\begin{array}{l}\text { Percentage } \\
\text { reduction }\end{array}$ & Point reduction \\
\hline AUS & 0.30 & 0.46 & 0.34 & 0.16 \\
\hline AUT & 0.27 & 0.43 & 0.39 & 0.17 \\
\hline BEL & 0.27 & 0.49 & 0.45 & 0.22 \\
\hline CAN & 0.32 & 0.44 & 0.27 & 0.12 \\
\hline CZE & 0.27 & 0.47 & 0.43 & 0.21 \\
\hline DNK & 0.23 & 0.42 & 0.44 & 0.18 \\
\hline FIN & 0.27 & 0.39 & 0.30 & 0.12 \\
\hline FRA & 0.28 & 0.48 & 0.42 & 0.20 \\
\hline DEU & 0.30 & 0.51 & 0.41 & 0.21 \\
\hline ISL & 0.28 & 0.37 & 0.24 & 0.09 \\
\hline IRL & 0.33 & 0.42 & 0.21 & 0.09 \\
\hline ITA & 0.35 & 0.56 & 0.37 & 0.21 \\
\hline JPN & 0.32 & 0.44 & 0.28 & 0.12 \\
\hline KOR & 0.31 & 0.34 & 0.08 & 0.03 \\
\hline LUX & 0.26 & 0.45 & 0.43 & 0.20 \\
\hline NLD & 0.27 & 0.42 & 0.36 & 0.15 \\
\hline NZL & 0.34 & 0.47 & 0.29 & 0.14 \\
\hline NOR & 0.28 & 0.43 & 0.36 & 0.16 \\
\hline POL & 0.37 & 0.57 & 0.34 & 0.20 \\
\hline SVK & 0.27 & 0.46 & 0.42 & 0.19 \\
\hline SWE & 0.23 & 0.43 & 0.46 & 0.20 \\
\hline $\mathrm{CHE}$ & 0.28 & 0.35 & 0.22 & 0.08 \\
\hline GBR & 0.34 & 0.46 & 0.27 & 0.13 \\
\hline USA & 0.38 & 0.46 & 0.17 & 0.08 \\
\hline OECD-24 & 0.30 & 0.45 & 0.34 & 0.15 \\
\hline
\end{tabular}

Source: OECD, Growing Unequal, (C) 2008 


\section{Figure 1. Reduction in Inequality Due to Public Cash Transfers and Household Taxes}

Point reduction in the concentration coefficient
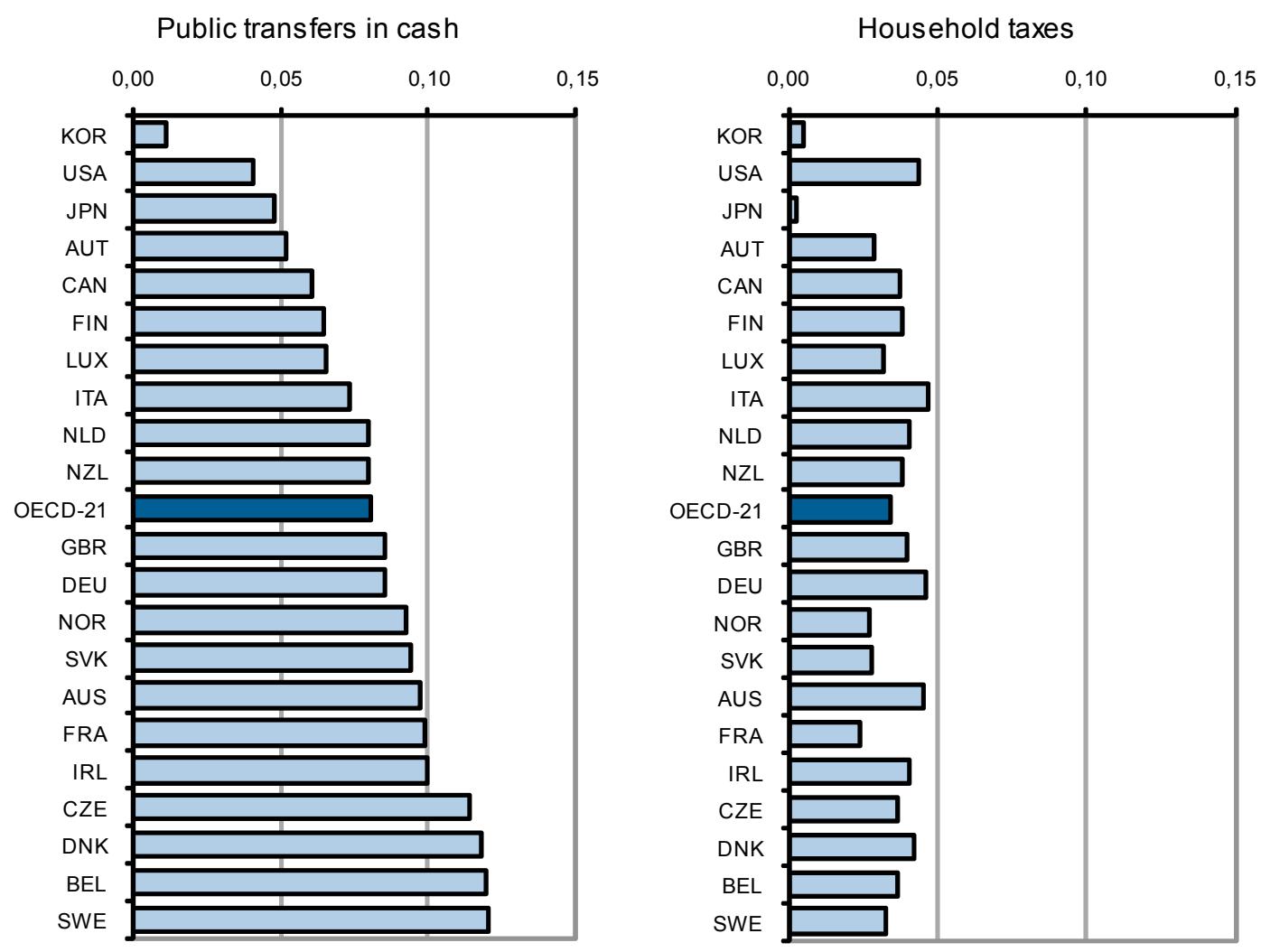

Source: OECD, Growing Unequal, (c) 2008

\section{CORPORATE INCOME TAX (CIT)}

19. The taxation of corporate profits in Iceland - a classical system - is generally in accordance with the systems that are found in other European countries. It is a consistent and efficient tax system that does not require major changes. There are specific aspects, however, where the current economic situation has brought to the surface some shortcomings related to the treatment of holding gains and losses, debt forgiveness, complex financial operations, and excessive leverage. This chapter deals with these topics, which probably apply primarily to relatively large corporations. Issues related to closely held corporations and incorporated self-employed workers, as well as to the CIT rate and its interaction with the PIT are covered below in a separate chapter, as they require the prior discussion of the PIT. 


\section{A. Financial Versus Tax Accounting}

\section{Issue}

20. The income tax law currently does not contain any rule dealing with the status of the financial statements for tax purposes. However, in practice, principles of accounting seem to play a certain role in determining taxable profit. This leads - amongst other - to uncertainty about the tax treatment of derivatives, an artificial and too broad definition of interest, and an undue deferral of the recognition of capital gains and losses on some assets.

\section{Analysis}

21. In most OECD countries the financial statements are - to a various degree - used as starting point to determine taxable profit. Some countries (e.g., Austria, Germany, and Hungary) use a strict linkage between financial statements and tax accounts, whereas other countries are more liberal in allowing deviations between financial statements and tax accounts in specific cases.

22. The main argument to use financial statements as the starting point is that they measure 'distributable' profit; i.e., profit that is not necessary for continuation of the business activities. As Iceland has adopted - in line with other European countries - the International Financial Reporting Standards (IFRS), another advantage would be the use of an internationally accepted income concept familiar to most investors. Finally, the tax system would benefit from the international experience gained in financial accounting, especially regarding the treatment of derivatives and other complex operations that are currently poorly covered by the tax law.

\section{Recommendation}

- Introduce the necessary provisions in the Income Tax Act that make the profit determined according to the financial statement the basis for the taxable profit, allowing only those deviations explicitly provided for in the Income Tax Act.

\section{B. Capital Losses and Debt Forgiveness}

\section{Issues}

23. Currently capital losses are only recognized upon realization. When recognized, they are ring-fenced and they cannot be offset against other income categories, such as income arising from debt forgiveness. Many corporations suffered significant capital losses during the crisis on their holdings of equity and other financial assets, to the extent that they are now in negotiations with creditors to restructure their debt. However, a successful completion of debt restructuring negotiations is hindered by the tax implications, as forgiven debt would give rise to taxable income that cannot be offset against the accounting losses. 


\section{Analysis}

24. Financial accounting rules typically recognize capital gains and losses on portfolio financial assets when they accrue - e.g., by using a mark-to-market valuation or other fair value methods. The idea is that those assets - as opposed to fixed assets or stakes held for strategic long-term investment purposes — can be easily made liquid. Most European countries use - to some degree - accounting rules to value their assets for tax purposes. As a consequence, most capital gains are taxed and losses deducted even if not (yet) realized.

25. Furthermore, all European countries, except for the United Kingdom and Ireland, treat capital gains and ordinary profit in the same manner for tax purposes; i.e., capital losses can be used to absorb ordinary profit. This treatment is justified since corporations maximize overall profit, and can freely distribute it regardless whether it relates to ordinary income or capital gains.

26. By applying financial accounting valuation for tradable financial assets in combination with the tax treatment of capital losses as ordinary income, debt restructuring becomes neutral for tax purposes in most cases. Creditors will forgive debt only if the debtor cannot fulfill its liability due to accumulated losses. In that case, the debtor would recognize the forgiveness of debt as taxable income, but would be able to absorb it with the accumulated tax losses. Any part of the forgiven debt in excess of losses would be a genuine net income and would be subject to tax.

27. This treatment however would not resolve legacy cases. In these, losses were incurred in the past and were accounted for according to the current tax treatment - that is, they may not have resulted in tax losses eligible for offsetting the income from debt forgiveness. A satisfactory resolution of these cases requires a one-time transitional treatment, which should provide guarantees against abuse.

28. In cases where the debtor is an individual taxpayer, the tax authority appears inclined to exempt income from forgiveness of mortgage debt to the extent this does not result in a debt below the fair market price of the residence. Arguably, however, the tax authority could accept a tax exempt debt forgiveness income slightly higher, as lenders could go below the market value of the residence by the extent of their foreclosure and disposal expenses.

\section{Recommendations}

- For companies, the income tax should follow the valuation provisions as used in the financial accounting rules.

- $\quad$ The income tax should treat as ordinary profits capital gains and losses on business assets that are recognized in accordance with financial accounting rules. Consequently, income arising from debt forgiveness should be considered taxable 
income but would be offset against these losses. Income in excess of losses, if any, should be taxed.

- A one-time transition mechanism should be adopted to allow the tax recognition of capital losses incurred during the crisis up to an amount commensurate to the income arising from debt forgiveness. This could be closely monitored and authorized by the tax administration on a case by case basis in accordance with publicly announced rules.

- $\quad$ For individuals, the tax authority should exempt income from mortgage debt forgiveness up to the point where the debt is equal to the market value of the property reduced by reasonable foreclosure and sale costs to the lender.

\section{Excessive Interest Deductions}

\section{Issue}

29. The corporate tax system in Iceland, as in most countries, introduces a bias in favor of debt - as opposed to equity - financing. This is because in the hands of the corporation, profits are taxable while interest payments are deductible. The tax authorities consider that there are indications of excessive debt financing, often motivated by tax avoidance objectives - such as the high amount of loss carry forward ${ }^{6}$ and highly leveraged takeovers followed by reversed acquisitions. ${ }^{7}$

30. At present, the tax authorities' only possibility to confront these practices is by using either the arm's length provision (article 57 ITA) or the anti-avoidance concept developed in case law. Neither of these approaches seemed to be effectively applicable in Iceland and the authorities consider that their capacity to challenge and prevent thin capitalization practices should be strengthened.

31. Within OECD countries, apart from the arm's length test (mainly used in the Nordic countries) one can distinguish two other main methods of protection against excessive debt financing (Table 5): the debt-to-equity ratio test, and the earnings test. Both place a cap on the amount of interest that can be deducted for tax purposes from the taxable base. In the discussion below, it is assumed that interest is computed based on IFRS (as recommended above) and therefore it does not include foreign exchange gains and losses, as it currently

\footnotetext{
${ }^{6}$ For 2007 a total loss carry forward of almost ISK 383 billion was reported, whereas the total revenue of income tax amounts to ISK 241 billion.

${ }^{7}$ Investors typically created an Icelandic subsidiary that acted as the acquiring company and was financed by debt. After the takeover this company was merged into the acquired company, so as to offset its interest expenses with the operational profit of the acquired company.
} 
does in Iceland for tax purposes. Also under both methods, financial institutions should be exempt from the caps on interest deductibility. A related approach to resolve the bias towards debt financing - the introduction of an Allowance for Corporate Equity (ACE) - is described in a later chapter of this report. It is not recommended at this time as it would likely have a negative revenue impact, as discussed in the corresponding chapter.

32. The debt to equity ratio test disallows any interest deduction on the part of the debt financing deemed excessive. This excessive part is established by the ratio between debt and equity. Any disallowed interest expense is not allowed to be carried forward. Countries applying this approach typically use an across-the-board debt-to-equity ratio. This approach has some disadvantages as it does not reflect the actual debt-to-equity ratios in the various industries. Another disadvantage is that the debt-to-equity ratio will be unstable due to indexation as the valuation of liabilities - and of equity (through the valuation of financial assets) - may fluctuate. The ratio depends further on whether equity is calculated on fair market value (requires a more narrow ratio) or tax value. If equity - as a result of accumulated losses - becomes negative, additional rules are needed. Also, the corporation could manipulate its equity around the test date in order to increase the allowed deduction. Finally, the limitation of the debt-to-equity test to related parties requires some antiavoidance rules regarding back-to-back loans and guarantees. The advantage of this test is that it is fairly predictable: corporations have in advance a good idea of how much debt they can take before breaching the test.

33. The earnings test limits the amount of deductible interest expense as a percentage of earnings before interest costs and tax (EBIT) or earnings before interest costs, tax, depreciation and amortization (EBITDA). This approach normally allows first the reduction of interest expenses up to the interest income received in the same year. In addition, any net interest expense-i.e., the excess interest expense over the interest received in the same year-is deductible up to a percentage of the EBIT. Often, the latitude for net interest expenses is broadened by using the EBITDA. Any non-deductible net interest expenses can be carried forward indefinitely. This rule is used in Germany and Italy, and it is being considered in the Netherlands. To prevent administrative difficulties and avoidance, the ratio of allowed interest to earnings is the same across industries as in the above mentioned debtto-equity test. This method could create difficulties in businesses with unusually volatile profits, which would see some legitimate interest costs disallowed in low-profit years and would be well below their allowed cap in good-profit years. A sufficiently generous limit (as when using EBITDA, for example) and the carry-forward provision, however, would mitigate this shortcoming. On the other hand, the allowable interest deduction ceiling is more uncertain ex ante than in the debt-to-equity test, as it is only known after profits are realized and the income statement is drawn. 


\section{Table 5. Thin Capitalization Rules}

\begin{tabular}{|c|c|c|c|}
\hline Country & Type & Application yield & Other \\
\hline \multicolumn{4}{|c|}{ Nordic countries } \\
\hline Denmark & Ratio & $\begin{array}{l}50 \% \text { share or voting } \\
\text { power }\end{array}$ & $\begin{array}{l}\text { The following limitations apply: } \\
\text { 1) debt-to-equity ratio of } 4: 1 \text {; } \\
\text { 2) net financing expenses }<7 \% \text { of tax value of } \\
\text { business assets; } \\
\text { 3) net financing expenses }<80 \% \text { of annual taxable } \\
\text { profits. }\end{array}$ \\
\hline Finland & $\begin{array}{l}\text { Arm's } \\
\text { length }\end{array}$ & Related parties & \\
\hline Norway & $\begin{array}{l}\text { Arm's } \\
\text { length }\end{array}$ & Related parties & \\
\hline Sweden & $\begin{array}{l}\text { Arm's } \\
\text { length }\end{array}$ & Related parties & $\begin{array}{l}\text { Interest deduction is disallowed in the case of a } \\
\text { loan by an affiliated company for the purpose of } \\
\text { acquiring a participation right in another (foreign) } \\
\text { affiliated company. }\end{array}$ \\
\hline \multicolumn{4}{|c|}{ Other EU countries } \\
\hline France & Ratio & $\begin{array}{l}\text { Associated parties } \\
\text { (i.e. } 50 \% \text { direct or } \\
\text { indirect share capital } \\
\text { or voting power) }\end{array}$ & $\begin{array}{l}\text { Three tests apply: } \\
\text { 1) overall debt-to-equity ratio }(1,5: 1) \text {; } \\
\text { 2) interest paid/realized profits }(1: 4) \text {; } \\
\text { 3) interest paid/interest received by associated } \\
\text { persons ( } 1: 1) \text {; } \\
\text { whereby the highest deductible amount increased } \\
\text { by EUR } 150,000 \text { is applied and any unused } \\
\text { amount is carried forward. }\end{array}$ \\
\hline Germany & Earning & & $\begin{array}{l}\text { Interest expenses are fully deductible up to the } \\
\text { amount of interest income of the same year; } \\
\text { Net interest expenses are deductable only up to } \\
30 \% \text { of earnings before interest, taxes, } \\
\text { depreciation and amortization (EBITDA); } \\
\text { Non-deductible net interest expenses are carry } \\
\text { forward unlimited. } \\
\text { Threshold of EUR } 3 \text { million. }\end{array}$ \\
\hline Ireland & & Related parties & $\begin{array}{l}\text { Interest on loans made between connected } \\
\text { companies used to acquire shares in a third } \\
\text { connected company are not deductible, unless } \\
\text { they are used to increase the working capital of the } \\
\text { group or where the interest can be matched } \\
\text { against related taxable income such as dividends } \\
\text { or interest receivable. }\end{array}$ \\
\hline Netherlands & Ratio & $\begin{array}{l}\text { Related parties (i.e. } \\
1 / 3 \text { of share or voting } \\
\text { power) }\end{array}$ & $\begin{array}{l}\text { Possibility to increase debt-to-equity ratio }(3: 1) \text { to } \\
\text { average group debt-to-equity ratio }\end{array}$ \\
\hline
\end{tabular}




\begin{tabular}{llll}
\hline Country & Type & \multicolumn{1}{c}{ Application yield } & \multicolumn{1}{c}{ Other } \\
\hline Spain & Ratio & $\begin{array}{l}\text { Non-EU related } \\
\text { persons }\end{array}$ & Debt-to-equity ratio of 3:1 \\
$\begin{array}{l}\text { United } \\
\text { Kingdom }\end{array}$ & $\begin{array}{l}\text { Arm's } \\
\text { length }\end{array}$ & $\begin{array}{l}\text { Related parties } \\
\text { UK companies (part of a large worldwide group) }\end{array}$ & $\begin{array}{l}\text { UK } \\
\text { that have net finance expenses, the available } \\
\text { aggregate deduction for interest is restricted to the } \\
\text { consolidated gross finance expense of the group. } \\
\end{array}$ \\
& & $\begin{array}{l}\text { The rule also provides for the exemption of } \\
\text { financing income where the has been a } \\
\text { disallowance as a result of the restriction. } \\
\text { ['worldwide debt cap'-regime] }\end{array}$
\end{tabular}

\section{Other OECD countries}

\begin{tabular}{|c|c|c|c|}
\hline Canada & Ratio & $\begin{array}{l}\text { Specified non- } \\
\text { resident } \\
\text { shareholders (i.e. > } \\
25 \% \text { of any class } \\
\text { share together with } \\
\text { non-arm's length } \\
\text { persons) }\end{array}$ & Debt-to-equity ratio of $2: 1$ \\
\hline $\begin{array}{l}\text { United } \\
\text { States }\end{array}$ & Facts & & $\begin{array}{l}\text { Factors that indicate thin capitalized corporations: } \\
\text { 1) whether the instrument contains a written } \\
\text { unconditional promise to pay on demand or on a } \\
\text { specified date a sum certain in money, in return for } \\
\text { adequate consideration, and to pay a fixed rate of } \\
\text { interest; } \\
\text { 2) whether the instrument is subordinate to or has } \\
\text { a preference over indebtedness of the corporation; } \\
\text { 3) the debt-to-equity ratio of the corporation; } \\
\text { 4) whether the instrument is convertible into stock } \\
\text { of the corporation; and } \\
\text { 5) the relationship between the holding of the } \\
\text { instrument and the stock of the corporation, i.e. } \\
\text { whether or not such holdings are proportional. }\end{array}$ \\
\hline
\end{tabular}

Source: Database Europe - Corporate Taxation, International Bureau of Fiscal Documentation, (C) 2010, Amsterdam

\section{Recommendation}

- A thin capitalization provision based on either the debt-to-equity ratio or the earnings test should be introduced. An earnings test based on EBITDA is possibly preferable due to its simplicity and lower potential for avoidance. 


\section{Interest Payments Abroad}

\section{Issue}

34. Iceland is confronted with an erosion of its corporate tax base by interest paid to creditors resident in low tax jurisdictions.

\section{Analysis}

35. Since 2010 Iceland levies a 15 percent withholding tax on interest payments to safeguard its corporate tax base. Most of the double tax treaties concluded by Iceland with other European countries reduce this withholding to 0 percent or provide for a tax credit. ${ }^{8}$ If the creditor is a resident of a tax haven country, the withholding tax is a final tax. In practice, the tax incidence of this withholding tax lies often with the debtor (including because contractual stipulations) and results in higher costs on borrowings from abroad. In the current economic situation, such increased finance costs are a hindrance to improving the investment climate.

36. The Nordic countries and some EU countries do not levy a withholding tax on interest paid to a nonresident company. A substantial number of European countries, however, levy withholding tax on interest payments to nonresident companies. They refrain from doing so only in cases where the Interest and Royalties Directive applies (Table 6). ${ }^{9}$

37. Thin capitalization rules alone may not be sufficient to avoid capital stripping to low tax jurisdictions. Some European countries - amongst which Belgium, France, Spain, and Italy - have provisions that disallow the deduction of interest paid if the creditor is resident in a low tax jurisdiction. A low tax jurisdiction could be defined as either a country with a lower nominal tax rate than 70 percent of the domestic nominal tax rate (for Iceland this would mean a rate of 12.5 percent, i.e. 70 percent of 18 percent) or a country with a lower nominal tax rate than the lowest in a certain region (for the EU this would mean a rate of 10 percent, i.e. the nominal rate applicable in Cyprus and Bulgaria), or by issuing a black list.

\footnotetext{
${ }^{8}$ The exemptions are the treaties with Estonia, Latvia, Lithuania, and Portugal which contain a withholding tax of 10 percent; the treaty with Greece contains a withholding tax of 8 percent; the treaty with Spain limits the withholding tax to 5 percent; and the treaty with Romania to 3 percent.

${ }^{9}$ Council Directive 2003/49/EC of 3 June 2003 on a Common system of Taxation Applicable to Interest and Royalty Payments Made Between Associated Companies of Different Member States.
} 


\section{Table 6. Withholding Tax on Interest Paid Abroad}

\begin{tabular}{ll}
\hline \multicolumn{1}{c}{ Country } & \multicolumn{1}{c}{ Withholding Tax on interest (Business to Business) } \\
\hline Nordic countries & \\
Denmark & $0 \%$ \\
Finland & $0 \%$ \\
Iceland & $15 \%$ \\
Norway & $0 \%$ \\
Sweden & $0 \%$ \\
Other EU countries & \\
Austria & $0 \%$ \\
Belgium & $15 \%$, Interest and Royalties Directive \\
Bulgaria & $10 \%$, Interest and Royalties Directive (5\% from 2011-2014; 0\% \\
& afterwards) \\
Cyprus & $0 \%$ \\
Czech Republic & $15 \%$, Interest and Royalties Directive \\
Estonia & $0 \%$ \\
France & $0 \%$ \\
Germany & $0 \%$ \\
Greece & $0 \%$ \\
Hungary & $30 \%$, Interest and Royalties Directive \\
Ireland & $20 \%$, Interest and Royalties Directive \\
Italy & $12.5 \%$, Interest and Royalties Directive \\
Latvia & $10 \%$, Interest and Royalties Directive (5\%, 0\% after June 2013) \\
Lithuania & $10 \%$, Interest and Royalties Directive \\
Luxembourg & $0 \%$ \\
Malta & $0 \%$ \\
Netherlands & $0 \%$ \\
Poland & $20 \%$, Interest and Royalties Directive (5\%; 0\% after June 2013) \\
Portugal & $20 \%$, Interest and Royalties Directive \\
Romania & $16 \%$, Interest and Royalties Directive (10\%; 0\% after 2010) \\
Slovak Republic & $19 \%$, Interest and Royalties Directive \\
Slovenia & $15 \%$, Interest and Royalties Directive \\
Spain & $19 \%$, Interest and Royalties Directive \\
United Kingdom & $20 \%$, Interest and Royalties Directive \\
\hline \multicolumn{1}{c}{ Source: Database Europe - Corporate Taxation, International Bureau of Fiscal } \\
$\quad$ Documentation, 0 \\
& 2010, Amsterdam \\
&
\end{tabular}

\section{Recommendation}

- $\quad$ The 15 percent withholding tax on interest payments to residents in treaty countries should be waived or reduced (as provided by the treaty) at source, using precertification of residence. This would make unnecessary for the creditor to request an ex post refund.

- $\quad$ The authorities could consider disallowing the deduction of interest payments made to residents in a low tax country. 


\section{E. Intercompany Dividends}

\section{Issues}

38. The tax treatment of intercompany dividends received by a parent company resident in Iceland is inconsistent with European practice. Furthermore, the tax treatment is potentially restrictive for legitimate long-term strategic investments in large companies by investors resident in Iceland.

\section{Analysis}

39. Currently dividends received from domestic and foreign subsidiaries are included in the tax base. A relief for double taxation of these dividends is provided for in the form of a deduction, if the parent company holds at least 10 percent of the capital in a subsidiary that is:

- a public limited company, a private limited company, or a partnership resident in Iceland;

- a similar type of company that is liable to tax and is resident in another country of the European Economic Area (EEA); or

- a public limited company registered in another country and is taxed abroad in a similar manner as it would be if it were a resident company in Iceland.

40. The deduction of intercompany dividends may not give relief for double taxation in cases of loss carry forward. As the carry forward of losses is effectuated as a deduction, it will potentially reduce the base from which to deduct intercompany dividends. This will especially be the case as long as Iceland does not have an unlimited carry forward of losses. Therefore, subsidiaries may want to refrain from any dividend distribution to their Icelandic parent company as long as it has carry-forward losses.

41. In European countries the double taxation on intercompany dividends is typically eliminated either by an exemption or by a credit for the underlying corporate income tax. Most countries choose for an exemption of the dividends received, ${ }^{10}$ whereby they may add back a small percentage of the dividend received as compensation for related expenses.

42. The introduction of a threshold of 10 percent of the shareholding is based on the intention to distinguish between portfolio and strategic business investments, whereby only

\footnotetext{
${ }^{10}$ Within the EEA and EU, only Belgium and Luxembourg follow a similar relief method as Iceland. Belgium was recently forced by the European Court of Justice in Case C-138/07 of 12 February 2009 (Cobelfret) to provide for an unlimited carry forward of the unused foreign dividend deduction.
} 
the latter will enjoy a relief for double taxation. However, an investment in a large corporation may not meet the minimum shareholding requirement, but nevertheless be considered a strategic long-term investment by the investing company.

43. In all Nordic countries a threshold of 10 percent of the shareholding is used (Table 7). This requirement is based on the Parent-Subsidiary Directive, ${ }^{11}$ which allows member states to have a minimum shareholding requirement not in excess of 10 percent. In Belgium and Luxembourg an additional alternative requirement for the intercompany dividend relief can be used. A parent company is eligible for this relief, if one of the following requirements is met: (i) holding - directly or indirectly — a capital participation of at least 10 per cent, or (ii) holding a minimum participation with an acquisition cost of at least EUR 1.2 million. In Iceland, this additional requirement could also be used with an appropriate threshold to facilitate long-term strategic investments in other companies.

\section{Table 7. Intercompany Dividends in Nordic Countries}

\begin{tabular}{|c|c|c|c|}
\hline Country & Method & Yield & Requirements \\
\hline Denmark & Exemption & $\begin{array}{l}\text { Dividends and } \\
\text { capital gains }\end{array}$ & $10 \%$ shareholding \\
\hline Finland & Exemption & Dividends & $\begin{array}{l}10 \% \text { shareholding; } \\
\text { If }<10 \% \text { shareholding, exemption is } 25 \%\end{array}$ \\
\hline Iceland & Deduction & $\begin{array}{l}\text { Dividends and } \\
\text { capital }\end{array}$ & $\begin{array}{l}10 \% \text { shareholding; for foreign shareholdings: } \\
\text { subject-to-tax clause }\end{array}$ \\
\hline Norway & $\begin{array}{l}\text { Exemption } \\
(97 \%)\end{array}$ & $\begin{array}{l}\text { Dividends and } \\
\text { capital gains }\end{array}$ & $\begin{array}{l}\text { None for domestic and EEA residents; } \\
10 \% \text { shareholding otherwise, } 2 \text { year holding period, } \\
\text { subject-to-tax clause. }\end{array}$ \\
\hline Sweden & Exemption & $\begin{array}{l}\text { Dividends and } \\
\text { capital gains }\end{array}$ & $\begin{array}{l}\text { Only if shares are considered business assets: } \\
\text { - unquoted shares } \\
\text { - quoted shares, only if }>10 \% \text { shareholding or } \\
\text { otherwise necessary for business conduct and } \\
\text { holding period of at least } 1 \text { year. }\end{array}$ \\
\hline
\end{tabular}

Source: Database Europe - Corporate Taxation, International Bureau of Fiscal Documentation, (C) 2010, Amsterdam

\section{Recommendations}

- The participation deduction should be reformed into a participation exemption, bringing the tax treatment of intercompany dividends in line with other European countries.

\footnotetext{
${ }^{11}$ Council Directive of 23 July 1990 on the Common System of Taxation Applicable in the Case of Parent Companies and Subsidiaries of Different Member States (90/435/EC).
} 
- The income tax should be amended to add to the current threshold of 10 percent shareholding a second (alternative) threshold in the form of a fixed amount of investment - calibrated to the specific situation in Iceland.

\section{F. Loss Carry Forward}

\section{Issue}

44. The high loss carry forward position of Icelandic business - as discussed before the loss carry forward reported in 2007 exceeded 150 percent of corporate tax revenue - may result in a substantial loss of revenue in the near future. Further limitation of the carry forward in time is being discussed.

\section{Analysis}

45. The possibility to carry forward losses for tax purposes mitigates tax disincentives to invest in businesses with volatile profits. Given the Icelandic economic circumstances, this is a necessary feature of the tax system. Any further limitation of the carry forward period may result in weakening the competitiveness of its business environment. It would also bring Iceland out of line compared to some of its major trading partners and competitors for capital (Table 8). Information on how Iceland compares with other OECD countries regarding the total amount of the loss carry forward is not available.

Table 8. Operational Losses

\begin{tabular}{|c|c|c|}
\hline Country & Carry Forward & Carry Back \\
\hline \multicolumn{3}{|c|}{ Nordic countries } \\
\hline Denmark & indefinitely & $\mathrm{n} / \mathrm{a}$ \\
\hline Finland & 10 years & $\mathrm{n} / \mathrm{a}$ \\
\hline Iceland & 10 years & $\mathrm{n} / \mathrm{a}$ \\
\hline Norway & indefinitely & $\mathrm{n} / \mathrm{a}$ \\
\hline Sweden & indefinitely & $\mathrm{n} / \mathrm{a}$ \\
\hline \multicolumn{3}{|c|}{ Other EU countries } \\
\hline France & indefinitely & 3 year (credit) \\
\hline Germany & indefinitely & 1 year (up to EUR 511.500) \\
\hline Ireland & indefinitely & $\mathrm{n} / \mathrm{a}$ \\
\hline Netherlands & 9 years & 1 year \\
\hline Spain & 15 years & $\mathrm{n} / \mathrm{a}$ \\
\hline United Kingdom & indefinitely & $\mathrm{n} / \mathrm{a}$ \\
\hline \multicolumn{3}{|l|}{$\begin{array}{l}\text { Other OECD } \\
\text { countries }\end{array}$} \\
\hline Australia & indefinitely & $\mathrm{n} / \mathrm{a}$ \\
\hline Canada & 20 years & 3 years \\
\hline New Zealand & indefinitely & $\mathrm{n} / \mathrm{a}$ \\
\hline United States & 20 years & 2 years \\
\hline
\end{tabular}




\section{Recommendation}

- $\quad$ Maintain the current 10-year period of loss carry forward.

\section{G. Investment Incentives}

Issue

46. Investment incentives - including tax reductions and potentially tax holidays - are currently being considered. Beneficiaries would qualify if they meet certain requirements, including a minimum turnover of ISK 300 million (approx. US\$ 2.3 million). The incentives could be obtained for investments in an area that covers almost the entire geographical area of Iceland, including areas close to Reykjavik.

\section{Analysis}

47. Incentives of this type typically distort the tax system since they create low tax areas that easily attract taxable profits from other areas rather than greenfield investment. On the medium term this would make it difficult to maintain the relative high level of taxation and compliance. In addition, the proposed incentives are not well targeted to attract major investment projects that would not take place otherwise and that play a key role in the growth prospects of the Icelandic economy.

\section{Recommendation}

- The investment incentives should not be adopted. If this is not feasible, the annual turnover requirement should be increased drastically in order to cover only very large investments of strategic value.

\section{Personal Income TaX (PIT) And Direct TaXes on Individuals}

\section{A. Allocating Labor and Capital Income within Closely Held Businesses}

\section{Issue}

48. The most salient problem with Iceland's dual income tax is misallocation of labor and capital income within closely held businesses. ${ }^{12}$ Because dual income tax systems tax income at different rates depending on whether it is generated by labor or capital, they require special rules for allocating income from closely-held companies whose owners contribute both capital and labor. In Iceland, this is done by stipulating that owner-employees attribute to

12 Sorensen (2007) describes this problem as "the Achilles heel" of dual income taxes. 
themselves an "arm's-length wage." Minimum imputed wages for owner-employees in different sectors and sizes of companies are published each year by the Finance Ministry. Closely held companies, whether they are sole proprietors, partnerships, or corporations, must impute wages for their owners and any family members working for the business. Imputed wages are subject to PAYE withholding, social security tax and compulsory pension savings.

49. For sole proprietorships, all income including residual profits is taxed at the relatively high personal income tax rates of 37.2-46.1 percent; only imputed wages are used to calculate withholding tax for this type of business. Residual profits of partnerships are subject to a special partnership tax rate, which is equal to the compound CIT and capital income tax rates. In 2008, with the CIT at 15 percent and the capital tax at 10 percent, the partnership rate was 23.5 percent $(=0.15+(1-0.15) * 0.10)$. In 2010 , as the CIT and capital income tax were both raised to 18 percent, the partnership tax rate was raised to 32.7 percent.

54. This advantageous tax regime for corporate profits and partnership income relative to labor income appears to have resulted in an explosion in the number of incorporated small businesses. By 2009, there were 30,162 corporate enterprises in Iceland-almost one per 10 inhabitants. For 2010, the authorities limited this tax-favored treatment of dividends by closely held corporations to 20 percent of net equity capital. Distributions in excess of this amount are split 50/50 between capital and labor income for tax purposes. Distributions attributed to labor are subject to social security as well as personal income taxes, and are deductible to the corporation in the current year. Introduction of this law in 2009 seems to have produced corporate conversions into partnerships.

\section{Analysis}

55. The current system of imputing labor income on the basis of government-specified minimum wages appears unsatisfactory. Returns to labor in small businesses can vary widely depending on proprietors' skills, effort and preferences in ways that are difficult to measure. Current imputed wage levels appear low and have not been raised since 2007 despite a more than 35 percent increase in the CPI over that period. For example, a professional (such as a doctor or lawyer) with more than 15 employees has imputed annual wages of ISK 8.7 million per year (US\$ 67,000), likely considerably less than such person could expect to earn in the private sector. The wave of incorporations since 1996 and the high overall number of corporations relative to the population (combined with the dearth of partnerships and sole proprietorships prior to 2010) suggest that the current income-splitting rules are viewed as highly advantageous and widely used for tax planning purposes.

56. A more effective method of allocating profits between labor and capital in closely held businesses is to ascribe capital income on the basis of a company's assets. Some variation of this method is used by other Nordic countries with dual income taxes. Sorensen 
(2007) and Cnossen (1999) describe the two principal methods for calculating capital income (Table 9):

- $\quad$ Under the gross assets method, an imputed return to assets is computed by multiplying total business assets by a reasonable rate of return on equity (" $R$ "), typically the intermediate-maturity government bond yield plus a moderate risk premium, or the interest rate on prime business loans. Labor income is the difference between pre-tax net profits (including owner's salary) plus interest paid and the imputed return to assets. Taxable profits (capital income) are the imputed return on assets less interest paid.

- $\quad$ Under the net assets method, an imputed return on equity is computed by multiplying net equity (total assets less debt) by the reasonable rate of return defined as above. Labor income is the difference between net profits (including owner's salary) and the imputed return on equity. Taxable profits (capital income) are the imputed return on equity.

If a business has no (or only trivial) assets, then all income will be ascribed to labor, as is appropriate. If $\mathrm{R}$ is the same as the interest rate charged on business debt, then the two methods are equivalent. Under either method, businesses can of course deduct the computed labor income as wage expense.

Table 9. Methods for Allocating Business Income Between Capital and Labor

\begin{tabular}{lccc}
\hline \multicolumn{1}{c}{ Method } & Capital Income & Labor Income & Country \\
\hline Gross Assets & $\mathrm{R}^{*}$ Assets - Interest & $\begin{array}{c}\text { Profits (including owner's } \\
\text { salary) + Interest - R*Assets }\end{array}$ & Norway \\
Net Assets & $\mathrm{R}^{*}($ Assets - Debt $)$ & $\begin{array}{c}\text { Profits (including owner's } \\
\text { salary) - } \mathrm{R}^{*} \text { (Assets - Debt) }\end{array}$ & Finland, Sweden \\
\hline$R=$ reasonable rate of return on equity, e.g. prime loan rate &
\end{tabular}

57. The gross and net asset methods have different strengths and weaknesses. The net assets method requires more elaborated accounting provisions to compute net assets and offers more opportunities for tax planning, typically requiring anti-avoidance rules. The gross asset method is simpler. But if $\mathrm{R}$ is greater than the interest rate paid on business debt, then companies have an incentive to undertake debt-financed investment (even if with a low return) in order to increase the share of their profits allocated to lower-taxed capital income.

58. Switching from an allocation formula according to which residual income is ascribed to capital to one that ascribes residual income to labor will reverse the marginal income tax rates faced by closely held businesses. Instead of high labor income tax rates on their initial income and lower capital income tax rates on their subsequent income, businesses will face the low capital tax rate for initial income and the higher labor tax rate for subsequent income. 
Thus their marginal rate will be low in low-income years and high in more profitable years. Switching to allocation of income based on assets is not expected to reduce revenues, but is also unlikely to increase them significantly in the near term.

\section{Recommendation}

- $\quad$ Allocate revenue in closely held businesses according to either the net or gross assets methods. The gross assets method would be preferable as it offers less opportunity for tax arbitrage. This income splitting regime should apply to both closely held corporations and partnerships.

\section{Issue}

\section{B. Increasing Revenue and Progressivity}

59. In 2010, revenue considerations and a desire to increase tax progressivity led the authorities to increase both labor and capital income tax rates. In 2009, they raised the basic labor income tax rate from 35.72 to 37.2 percent, and in 2010 introduced two surcharges of 2.9 percent on incomes above ISK 2.4 million and 6 percent on incomes above ISK 7.8 million. The authorities also raised the capital income tax rate from 10 percent to 15 percent in mid-2009 and to 18 percent in 2010. They also introduced two additional allowances: one for the first ISK 100,000 (US\$ 770) of interest income and another for 30 percent of the income from the renting of residential property. Finally, a net wealth tax was adopted. This tax has a rate of 1.25 percent and applies to net wealth (real estate and capital assets less debt) in excess of ISK 90 million (US\$ 692,000) for individuals and ISK 120 million (US\$923,000) for couples.

60. Further tax changes are being discussed including a possible switch to a comprehensive income tax, under which both labor and capital income would be taxed at progressive rates. To offset the resulting higher tax burden on real capital income due to inflation, the authorities have concomitantly considered reducing the taxable interest and capital gains by some proportional allowance in order to avoid taxing inflationary returns. Important considerations with respect to this decision include the tax elasticity of the capital income tax base and the effect of inflation on real tax rates on capital.

\section{Analysis}

61. Since the early 1980s, all of the Nordic countries have introduced dual income tax systems, ${ }^{13}$ which have the common feature of taxing capital income at a lower, uniform rate

\footnotetext{
${ }^{13}$ Denmark, who pioneered the dual income tax in 1987, has largely abandoned it, but Norway, Sweden and Finland retain the dual income tax systems they adopted in the early 1990s. Even without a full dual income tax system, most countries apply a lower rate to all or part of capital income.
} 
than the progressive rate levied on labor income. Because capital income is increasingly mobile across international boundaries, it is more difficult than labor income to tax at high progressive rates. The Nordic countries thus found that by lowering tax rates on capital income, they actually increased their revenue collections. Low, uniform rates on capital income also serve to encourage savings, to discourage tax arbitrage among different types of capital income, and to reduce the "lock-in" effect of capital gains taxation and mitigate the taxation of compensation for inflation.

62. Taxation of capital income in Iceland is complicated by the country's high and volatile inflation rate, derived in large part from exchange rate volatility. Since 1990, Iceland has had average annual inflation rate of almost 5 percent, with a standard deviation of 3.5 percent. When a substantial portion of the nominal return on assets represents compensation for inflation, as is typically the case with interest income, taxation based on nominal income can magnify the tax burden on the real return. ${ }^{14}$ Critics of the recent increase in capital income tax rates argue that, while gross investment income taxation at 10 percent was acceptable to most investors, significantly higher rates (even the current 18 percent) foment political pressure to shift the tax base to net or real investment income. The pressure to create exemptions in the presence of higher rates can be gauged from the creation of an ISK 100,000 interest exclusion that accompanied the recent capital income tax rate increase from 10 to 18 percent.

63. Iceland's capital income tax base is viewed as sensitive to tax rates, particularly at the high end of the income spectrum. Discussions with different experts indicate that individuals with about ISK 100 million or more in financial assets (that is, in the top one percent of the population in terms of assets) could profitably move those assets offshore. Investigations and official reports in the wake of the financial crisis underpin the broadly held view capital flight has taken place, at least in the recent past, despite the low then prevailing capital income tax rate of 10 percent, but naturally, no data on those holdings is available. ${ }^{15}$ Existing foreign exchange controls would forestall capital flight in reaction to higher capital taxes in the near term, but they will eventually be repealed. It is more difficult for less wealthy individuals to avoid taxes on income paid out by financial intermediaries; however, higher capital tax rates would exacerbate incentives for underreporting income.

64. Switching from a dual income tax to a comprehensive income tax would raise the basic capital income tax rate almost 20 percentage points to 37.2 percent, and the top marginal tax rate on capital income almost 30 points to 46.1 percent. Combined with effects of inflation, these rates would eliminate most of the real return on interest income (which

\footnotetext{
${ }^{14}$ For example, if the nominal interest rate is 10 percent and inflation is 5 percent, then an 18 percent tax on nominal interest income taxes the real return on bonds, 5 percent, at a 36 percent rate.

${ }^{15}$ Some "flight capital" returns to the country as foreign portfolio investment.
} 
accounted for 55 percent of total capital income reported in 2008). Accompanying this increase in rates with a partial exclusion or indexation for inflation would of course reduce the effective tax rate on capital income, though at the cost of reducing any expected revenue gain and, crucially, increasing the complexity, compliance costs, and avoidance opportunities of the tax system. Based on 2008 tax data, two-thirds of financial income was reported by the top ten percent of taxpayers in terms of income, whose capital income would likely be subject to the top rate. These taxpayers are the most likely to have access to offshore vehicles and other tax avoidance mechanisms. It is thus likely that shifting to a comprehensive income tax would fail to raise any significant revenue, particularly if it necessitated a partial exclusion or indexation of capital income, and might even reduce it.

65. There is, however, room to further increase progressivity by increasing labor and capital income tax rates somewhat without losing the positive features of Iceland's dual income tax or bringing tax rates out of line with other Nordic countries. The following covers potential changes to the progressive personal income tax schedule that applies to labor income, while the following chapter discusses the taxation of capital income at both the personal and corporate level.

66. Iceland's basic tax credit of ISK 530,466 (US\$ 4,080), which at the basic labor income tax rate of 37.2 percent shields ISK 1.4 million (US\$ 11,000), is high by Nordic standards (Table 10). In 2007, it equaled approximately 28 percent of average wage income. By comparison, Norway had the closest ratio at 16-24 percent, but other countries were significantly lower. Denmark had a ratio of 12-14 percent, Sweden 4-9 percent, and Finland 2-3 percent. Almost forty percent of taxpayers fall into this initial zero-rate bracket (although many of these are the very young, since Iceland requires tax filing from the age of 16).

67. Iceland's initial rate of personal income tax of 37.2 percent - comprising the central government rate of 24.1 percent and the local government average rate of 13.1 percent-is also high by Nordic standards. Sweden, Finland and Norway have initial rates of approximately 28 percent. Although Iceland's labor participation rate is high, this large initial rate could potentially discourage low-skilled workers from employment or divert them into the informal economy. Given the comparatively high initial income exemption and tax rate, further increases in progressivity should not be sought by increasing the basic tax credit or the initial 37.2 percent tax rate.

68. The first income tax bracket of individuals subject to a 37.2 percent marginal rate is extremely narrow, comprising only about 11,000 taxpayers or about 4 percent. The first surcharge of 2.9 percent is moreover a fairly low rate increment. The narrowness of the bracket and the low rate of the surcharge are almost tantamount to raising the basic rate by 2.9 percent, which is undesirable given the high initial rate. The second surcharge of 6 percent also affects a very small population of taxpayers - again, about 11,000 or 4 percent of all taxpayers - although this group accounts for a disproportionate share of labor income (slightly more than 10 percent). 
Table 10. Comparison of Nordic Dual Income Tax Systems (In percent of)

\begin{tabular}{lccccc}
\hline Country & $\begin{array}{c}\text { Basic Tax } \\
\text { Exemption } \\
\text { (\% of average } \\
\text { wage) }\end{array}$ & $\begin{array}{c}\text { Corporate } \\
\text { Income } \\
\text { Tax Rate }\end{array}$ & $\begin{array}{c}\text { Personal } \\
\text { Capital } \\
\text { Income Tax } \\
\text { Rate }\end{array}$ & $\begin{array}{c}\text { Lowest } \\
\text { Labor } \\
\text { Income Tax } \\
\text { Rate }\end{array}$ & $\begin{array}{c}\text { Highest } \\
\text { Labor } \\
\text { Income Tax } \\
\text { Rate }\end{array}$ \\
\hline Iceland (2010) & 28 & 18 & 18 & 37.2 & 46.1 \\
Finland (2007) & $2-3$ & 26 & 28 & 27.4 & 50.9 \\
Norway (2007) & $16-24$ & 28 & 28 & 28 & 49 \\
Sweden (2007) & $4-9$ & 28 & 30 & 31.5 & 56.5 \\
\hline
\end{tabular}

Source: OECD Taxing Wages (2008), Sorensen (2007)

69. A simpler and more progressive rate structure would be to levy a single higher surcharge of 10 percent on all individuals with at least ISK 4.5 million (US\$ 35,000) in wage income. This would raise approximately 0.25 percent of GDP in additional revenue and increase progressivity. If the government desires to retain three tax brackets and raise more revenue, the lower surcharge threshold could be raised to ISK 3 million (US\$ 23,000) and the surcharge rate be raised to 5 percent, while the higher surcharge threshold could be lowered to ISK 6 million (US\$ 46,000) and the surcharge rate lowered to 5 percent. This alternative raises about 0.43 percent of GDP but is slightly less progressive than the single-rate alternative because it does not relieve as many lower-income individuals from the first surcharge.

70. The net wealth tax introduced in 2010 is similar to an increased marginal tax rate on high capital income. A wealth tax is tantamount to an income tax levied on an imputed rate of income generated by capital assets. At the prevailing capital income tax rate of 18 percent, a 1.25 percent wealth tax implies an imputed rate of return on assets of 7 percent $(0.07 * 0.18$ $=0.0125)$. The new tax thus implies a total tax rate of 36 percent on taxpayers with very high net assets, who comprise less than one percent of the population (but hold 20 percent of net assets and receive 10 percent of income, approximately). The authorities expect that this tax will raise ISK 3.5 billion (US\$27 million) per year.

71. Financial experts cite several criticisms of the new wealth tax, which requires valuation of business equity based on Icelandic fiscal accounting. Taxpayers with shareholdings in non-traded companies can find their equity difficult to value, particularly if those companies hold shares in other non-traded companies carried at book value. This difficulty could be addressed by allowing shareholders to value their equities at current book value, regardless of whether they hold shares in other companies. Payment of the tax could also potentially cause liquidity problems where assets are not readily fungible; however, most high-net-wealth individuals also have substantial income and/or liquid assets. 
72. At the other end of the wealth spectrum, the new exemption for up to ISK 100,000 of interest income creates a zero-bracket rate for capital income. The cost of this tax expenditure in 2010 will be approximately ISK 2 billion (US\$ 15 million). These marginal changes at the very low and very high ends of the capital income tax do not greatly undermine its simplicity and integrity, but the authorities should refrain from introducing additional complexity, which could encourage financial arbitrage and/or capital flight.

73. Further, due to the high concentration of capital among high-income taxpayers, a flat proportional tax on capital income is inherently progressive. The Gini coefficient for capital income in Iceland, 0.42, is markedly higher than the Gini coefficient for labor income, 0.33. The top 50 percent of taxpayers receive about 80 percent of capital income, and the top 10 percent receive about 65 percent. Thus a progressive rate structure is not necessary in order to render capital income taxation progressive.

74. The social security tax, which funds unemployment insurance as well as some redistributive benefits, was raised from 5.34 percent to 8.65 percent in response to the increase in the unemployment rate resulting from the financial crisis. An increase in social security tax is justified to maintain the solvency of the unemployment and basic pension funds. To the extent that higher income groups receive more of their income from capital than lower-income groups, however, an increase in proportional taxes on labor income is regressive. The long-run incidence of an increase in wage taxes will be on workers, as real wages fall to offset the additional cost to employers. In the short run, the incidence may fall on employers locked into wage agreements, reducing employment growth. Therefore, considerations of both equity and job creation advise the eventual reduction of the social security tax rate when revenue pressures abate.

75. The current treatment of mortgage interest is inconsistent with the principles of income taxation, according to which interest would be deductible, but owner-occupiers would be taxed on commensurate imputed rents. As Iceland allows a tax credit for mortgage interest without rent imputation, its tax code encourages overconsumption of housing. If the purpose of the mortgage interest tax credit is to stimulate homeownership among segments of the population that would not otherwise be able to afford a house, then it does not fulfill this role efficiently: In 2008, almost 50 percent of mortgage tax credits went to taxpayers with above-median income, and despite means testing 10 percent went to individuals in the top 20 percent of the income distribution.

76. Clearly, in the current situation, in which approximately 40 percent of mortgage holders owe more than the market value of their houses, curtailing the mortgage tax credit could cause undesirable hardship. However, in order to prevent the tax code from encouraging future real estate market bubbles, the mortgage credit should be phased out or limited to low-income first-time buyers when incomes and housing values recover. Alternatively, owner-occupiers could be taxed on imputed rent, but given the administrative 
complexity that it entails, elimination or reduction of the mortgage interest credit is the simpler solution.

77. The current method of taxing rental income, which subjects 70 percent of gross rental income to the standard capital tax, offers administrative simplicity. The 30 percent exclusion constitutes a standard deduction for rental-related expenses. Given the simplicity of Iceland's business code, proprietors with substantially higher expenses have the option of placing their rental property within a business in order to take advantage of those deductions.

\section{Recommendations}

\section{Near-term}

- $\quad$ Retain the dual income tax.

- Do not raise the basic tax credit or initial tax rate.

- If needed, to increase progressivity and raise revenue, introduce a single 10 percent surcharge on incomes above ISK 4.5 million.

- $\quad$ Simplify net wealth tax by allowing the use of financial accounting valuations.

\section{Medium-term}

- $\quad$ Reduce social security tax rate as budgetary pressures decline.

- $\quad$ Phase out the mortgage interest deduction over time for all but low-income, first-time home buyers.

\section{CAPITAL INCOME TAXATION AND CORPORATE INTEGRATION}

\section{Issue}

78. With the objective of raising revenue in a progressive manner, the government has raised tax rates not only on labor and personal capital income, but on corporations as well, having increased the CIT rate from 15 to 18 percent in $2010 .{ }^{16}$ There is some leeway to increase these rates further, based on their level in comparison to other Nordic countries. In choosing how to raise them, the relative elasticity of personal savings and foreign investment should be taken into account, as well as their relationship to labor income tax rates.

\footnotetext{
16 The CIT rate was cut from 18 to 15 percent in 2008 .
} 
79. While interest, dividends and capital gains are currently taxed at a uniform rate at the individual level, their disparate treatment at the corporate level, where interest is deductible, provides a tax advantage for debt over equity finance that Iceland may wish to reduce in the medium term in order to discourage excessive leverage.

\section{Analysis}

80. Relative to other Nordic countries, Iceland's CIT and capital income tax rates, at 18 percent, are comparatively low. Finland, Norway and Sweden have CIT rates of 2628 percent (commensurate with their 28-30 percent personal capital income tax rates). Iceland's current CIT rate is similar to that of other small, open European economies, and neighbor Ireland has a low 12.5 percent rate.

81. Under a classic dual income tax, the tax on capital income is set equal to the lowest tax rate on labor income. This reduces the incentive to misallocate labor and capital income for moderately profitable companies. Whereas in most Nordic countries, capital income from unincorporated enterprises is subject only to individual-level capital taxation, Iceland's tax regime wisely harmonizes the tax rate on profits from private corporations and partnerships by subjecting partnership profits to a special tax rate equal to the compound rate on CIT and personal capital income: $0.327=0.18+(1-0.18) * 0.18 .{ }^{17}$ It is therefore this rate, rather than the personal capital tax rate, that should ideally be equalized with the lowest tax on labor income. Since the current combined corporate and individual rate on capital income is 32.7 percent, while the lowest tax rate on labor income is 37.2 percent, some combination of higher CIT and capital income tax rates could narrow or eliminate this gap, raising the combined tax rate on capital income by up to 4.5 percentage points.

82. The relative increase in the CIT and capital income tax rates should depend inversely on the elasticity of their bases. Generally, it is believed that capital income can be taxed more easily at the personal level than the corporate level. Multinational corporations responsible for much foreign direct investment (FDI) allocate resources internationally partly in response to tax differentials, and even domestic corporations can often strip income out of high-tax jurisdictions using debt and offshore vehicles. Conversely, individuals are viewed as being less internationally mobile. However, several experts and academics consider FDI in Iceland to be fairly tax insensitive, being attracted by low energy costs and other natural resources. At the same time, Iceland's high net worth individuals - a very small share of the population, but a substantial share of capital income - are viewed as being quite tax sensitive.

83. Given the uncertainty regarding the elasticity of the two bases, there is an argument for preserving the current equality of the CIT and personal capital income tax rates. When the two rates are equal, there is not a significant incentive for individuals to set up personal

\footnotetext{
${ }^{17}$ All income from a third type of private business, sole proprietorships, is taxed jointly with labor income.
} 
investment corporations to hold their capital assets (accumulating undistributed profits), rather than be taxed on their income as individuals. To equalize the combined capital and basic labor tax rates at 37.2 percent, the CIT and capital income rates could be raised up to 20.75 percent each. This report suggests as an option a more modest increase of two percentage points each, to 20 percent. This increase in the CIT rate is estimated to raise about 0.13 percent of GDP, while the similar increase in the capital income tax is estimated to raise about 0.3 percent of GDP.

84. Although income from debt and equity is subject to the same tax rate at the personal level (as is appropriate for preventing financial arbitrage), their disparate treatment at the corporate level, where interest but not profits are deductible, creates a tax advantage for debt finance. Under the current system, the total tax rate on dividends and capital gains is 32.7 percent (although the effective rate on capital gains may be reduced by deferral, since they are taxed on realization even at the corporate level), while for interest income it is only 18 percent. Reduction of this disparity would discourage excessive reliance on debt finance by Icelandic businesses in the future.

85. In order to ensure the financial neutrality of the tax regime, a pure dual income tax system would equalize the total tax rate on debt and equity income. This can be done either by reducing the taxation of dividends and capital gains on shares at the individual level (to offset the deductibility of interest at the corporate level), or by equalizing their treatment at the corporate level by introduction of a modified allowance for corporate equity (ACE).

86. Methods for equalizing the total taxation of capital income at the individual level include dividend imputation or exclusion and a step up in the basis for capital gains based on retained earnings. Under dividend imputation, individual taxpayers receive a tax credit for corporate income taxes paid on earnings distributed as dividends. The full pre-CIT value of the dividend is included in their taxable capital income, and their tax liability is reduced by the value of the prepaid CIT. To alleviate the double-taxation of capital gains, shareholders can be allowed to increase the basis of their shares each year by the amount of total retained earnings on which CIT has been paid. One caveat regarding this system is that the European Court of Justice has ruled that, unless dividend tax credits are extended to foreign as well as domestic shareholders, dividend imputation interferes with the free movement of capital. Most EU members that had imputation schemes have therefore shifted to a less accurate system of relief based on partial dividend exclusion, whereby only a percentage (fixed across all taxpayers) of dividend income is included in taxable income.

87. Rather than breaking the symmetry of capital income taxation at the individual level, introducing opportunities for tax arbitrage, a better solution may be equalizing (or narrowing) the treatment of debt by introduction of a modified ACE. The modified ACE provides a deduction for a normal return on assets (both equity and debt financed) calculated as assets times a "normal rate of return" (for example the rate on medium-term government bonds). Returns on equity (profits) and interest payments in excess of the normal return are taxed. 
This removes from the corporate tax base the opportunity cost of equity capital. It requires an increase (potentially large) in the nominal tax rate to maintain the same revenue yield. On the face of it, an ACE would radically redistribute the burden of taxation between different companies - those earning below the average return on assets gaining and those with a higher rate of return losing. Notice that the modified ACE would address the issue of excessive debt financing, thin capitalization, and excessive interest deductions discussed in the CIT chapter of this report. At present, only Belgium in the EU has an ACE applied only to equity returns (interest is deductible under standard rules). The creditability of this type of tax for foreign investors in their home country is subject to uncertainty.

\section{Recommendations:}

- If additional revenue is needed, increase both CIT and capital income tax rates to 20 percent.

- $\quad$ Over the medium term, consider reducing the double taxation of dividends and capital gains by introducing a modified ACE.

\section{VAlue Added Tax (VAT)}

88. The value added tax (VAT) in Iceland is a very productive tax. In 2008, it raised a higher proportion of GDP than in any other OECD country, despite the fact that, at that time, it did not have quite the highest VAT rate in the OECD. Nonetheless, Iceland's VAT does contain some inefficiencies, and the removal of some of these could raise substantial revenues. The main of these inefficiencies are the reduced rate, exemptions, and the treatment of unrecoverable input VAT for local authorities.

\section{A. The Reduced Rate}

\section{Issue}

89. VAT is ideally a tax on all consumption expenditure at a uniform rate that results in minimal distortion. The use of lower VAT rates on specific goods and services moves away from this ideal, introducing economic distortions, complicating the administration of the tax and losing revenue. Nonetheless, many countries have lower rates in the belief that it helps lower income families who spend a particularly high proportion of their incomes on these goods.

\section{Analysis}

90. The general argument against lower rates is that they provide a larger absolute reduction in tax for those on higher incomes and so is poorly targeted on lower income families; it would be better to subject all goods and services to the main VAT and use some 
of the resulting extra revenue to increase social benefits. In the specific case of Iceland, data from the household survey indicate that the percentage of expenditure on the items covered by the reduced rate is 22.3 percent for those in the bottom quarter of the income distribution as compared to 21.4 percent in the population as a whole. That is, the share of expenditure on low-rate goods among the poor is not significantly higher than among the total populationmaking the redistributive value of the low rate likely negligible.

91. The results indicate that the cost to those in the bottom quartile of increasing the VAT on these goods to 25.5 percent is 3.85 percent of their expenditure as compared to 3.70 percent for the population as a whole; a very small difference. The estimated consequences of moving towards a uniform VAT are shown in Table 11.

92. This removal of the lower rate of VAT would raise about 1.8 percent of GDP. Although the burden of this increase would only be slightly regressive, we propose that one third of this be used to finance an increase in income-tested benefits such as the child tax credit and means-tested pensions in order to protect those on lower incomes. The overall package would then be to increase both revenue and progressivity.

93. When additional revenue needs become less pressing, some of the funds could be used to reduce the main rate of VAT (thus reducing the incentives for fraud and evasion that currently exist).

\section{Table 11. Revenue and Price Effects of VAT Reforms}

(In percent of)

\begin{tabular}{cccc}
\hline $\begin{array}{c}\text { Proposed change } \\
\text { without compensation }\end{array}$ & $\begin{array}{c}\text { Revenue effect } \\
\text { with compensation }\end{array}$ & Price effect \\
\hline $\begin{array}{c}\text { Removal of the reduced } \\
\text { rate }\end{array}$ & $+1.8 \%$ of GDP & $+1.2 \%$ of GDP & $+3.6 \%$ \\
$\begin{array}{c}\text { Raising the reduced rate } \\
\text { to } 14 \% \text { and restricting it } \\
\text { to food purchases }\end{array}$ & $+1.1 \%$ of GDP & $+0.8 \%$ of GDP & $+2.2 \%$ \\
$\begin{array}{c}\text { Removal of non-EU } \\
\text { exemptions }\end{array}$ & $+0.6 \%$ of GDP & $+0.3 \%$ of GDP & $+1.2 \%$ \\
\hline
\end{tabular}

Source: IMF staff (C) 2010

94. If such an increase is too difficult to implement in a single step, a second-best option would be take a first step by restricting the lower rate to food items (excluding for example restaurant meals) and to reverse the reduction in the lower rate that was implemented a few years ago, increasing the lower rate to 14 percent. This would have a smaller distributional effect but still raise about 1.1 percent of GDP in additional revenue $(0.7$ percent from increasing the lower rate and 0.4 percent from moving non-food items to the 25.5 percent 
rate). In order to make this proposal progressive, we suggest that over a quarter of this additional revenue be used to finance increased income-tested benefits.

95. It is recognized that such increases in consumption taxation can be expected to increase the consumer price index and so increase the mortgage servicing costs to homeowners. However, any tax increase is likely to lead to price increases at some point in the future.

\section{Recommendation}

- $\quad$ Move to a single rate of VAT. Ideally, this would be achieved in a single step. However, if necessary, it could be staged, with a first step that raises the reduced rate back to 14 percent and restricts it to food. These changes should be accompanied of a compensation package for the low income sectors of the population, which indicatively could represent between a quarter and a third of the revenue gain.

\section{B. The Exemptions}

\section{Issue}

96. Iceland has a number of VAT exemptions that go beyond those included in the EU VAT Directive: sports, passenger transport, authors, composers, burials and travel agents.

\section{Analysis}

97. The general arguments both for and against exemptions are usually similar to those for a reduced rate of VAT. However, there is an additional argument against exemptions, which is that it can break the refund chain if any of the exempt services are purchased by businesses.

98. In the case of Iceland, there is no distributional argument for these exemptions as those in the lowest quartile spend a smaller proportion of their expenditure on these items (7.5 percent) that does the population as a whole ( 8.3 percent). It is hard to estimate exactly how much additional revenue would be collected because of the unrelieved input VAT that is currently collected but, if it is assumed that input subject to VAT represent no more than 40 percent of the value of the outputs, the application of the main VAT rate to these services could raise about 0.6 percent of GDP.

99. This change would increase the cost of public transport, which accounts for less than a third of the expenditure on these items. If government policy is against an increase in fares for public transport, it could use one third of the funds generated to finance a compensation package of direct subsidies to public transport while still generating significant additional revenue. 


\section{Recommendation}

- $\quad$ Remove the VAT exemptions from those items that are not included in the EU VAT Directive and use one third of the additional revenue to subsidize public transport.

\section{Unrecoverable Input VAT}

Issue

100. As in other European countries, Iceland's local authorities are exempt from VAT. This results in a disincentive for outsourcing local government services to the private sector. The problem is how to minimize the distortion that is caused by the exemption.

\section{Analysis}

101. The only full solution to this problem would be to remove the VAT exemption from local authorities so that they would have to charge VAT on their taxes and service charges but would also be able to reclaim input VAT, as in New Zealand. However, as this is inconsistent with the EU VAT Directive, European countries have adopted a different approach: reimbursing local authorities for some of their unrecoverable input VAT.

102. Iceland follows the European approach but the local authorities claim that only a small proportion (about 12 percent) of their input VAT is reimbursed. However, this does not necessarily mean that it causes a distortion, as the distortion only arises in relation to services that could be outsourced. So, provided all input VAT is reimbursed for services that could be outsourced, the above problem would be avoided.

103. If the central government does decide to reimburse a larger proportion of input VAT, this would increase the real resources available to local government and possibly lead to an increase in total government expenditure. This could be avoided by reducing other income to local authorities but the reduction in individual local authority income should not be related to the amount of VAT reimbursement that they receive. Otherwise, the original distortion would reappear. This means that it may be difficult to prevent local government expenditure from rising without redistributing resources between localities. In the current fiscal situation, it is therefore necessary to limit reimbursements to services that are definite possibilities for outsourcing.

\section{Recommendation}

- $\quad$ Provide reimbursement for input VAT to local government services that could be outsourced. In the current fiscal situation it is best to limit the reimbursements to those services. 


\section{OTHER TAXES}

\section{A. Recurrent Taxes on Immovable Property}

\section{Issue}

104. Property taxes are not high by international standards. Taxation of immovable property is relatively non-distortionary and residential property is favored by the rest of the tax system. As part of a revenue mobilization package, increases in property taxes could be considered as an option.

\section{Analysis}

105. Recurrent taxes on immovable property, especially residential property, can offset tax preferences in the income tax and capital gains tax that lead to excessive investment in housing. In addition, its immobility makes it a relatively non-distortive tax base from an efficiency standpoint. The general argument against it is that it is a particularly unpopular tax and is often seen as unfair.

106. In Iceland, as in most other OECD countries, immovable property is taxed by local authorities. However, this does not prevent an increase in the rate of tax contributing more generally to government revenue, by reducing the maximum rates of the local income tax and/or the size of the redistribution fund.

107. Although Iceland's property taxes are high by Nordic standards, there are a number of OECD countries that have considerably higher revenues from this source. In addition, the advantage of the immovable nature of the tax base is particularly applicable to a small island like Iceland with a very open economy.

108. The disadvantage of a property tax is that it can be seen as unfair, and this is the likely reason why local authorities often do not set the maximum allowable rate of property tax even when they set the maximum rate of personal income tax. The main difficulty relates to people with valuable property but low income, usually retired people, who may suffer hardship in case of a rate increase. Many OECD countries reduce the property tax for such groups, although it reduces the incentives for improving the allocation of the housing stock. An alternative solution is applied in some jurisdictions, in which the reduction in the property tax is treated as a loan that is repaid with interest from the estate of the owner when they die.

109. A large and sudden increase in property taxes would be difficult for Icelanders to accept in the current situation of widespread excessive housing debt. Nonetheless, in the long term, an increase in this tax would improve the efficiency of the tax system. 


\section{Recommendation}

- A raise in the rates of recurrent property taxes, particularly on residential property, should be considered as the housing market and incomes recover.

\section{B. Stamp Taxes}

Issue

110. Should Iceland reduce its stamp taxes on financial transactions and the sale of immovable property, as they are more distortionary than taxes on income, consumption and wealth?

\section{Analysis}

111. These taxes produce barriers to the reallocation of finances and real capital. In addition, they can be inequitable as the need to make these transactions (perhaps because of a change in employment) will often not be related to income or wealth. The only general argument against reducing them is that they are often more acceptable than other taxes because of their low rate.

112. In the case of Iceland, the argument for reducing these taxes is particularly strong because of the various shocks that affect a small open economy often require the reallocation of assets and changes to financial arrangements. The potential distortionary effect of these taxes is, therefore, particularly strong in Iceland. However, they do currently raise revenues of about 0.3 percent of GDP. This means that they can only be reduced if sufficient other tax revenues become available.

\section{Recommendation}

- $\quad$ The stamp taxes should be reduced or eliminated when the fiscal situation allows it.

\section{Excises on Food}

\section{Issue}

113. Should Iceland continue with its excise duties on foods with high sugar content in view of the complexity that they introduce in the tax system and their probable ineffectiveness in promoting healthy eating?

\section{Analysis}

114. The argument for maintaining them is that they discourage unhealthy eating. The argument against them is that they introduce complexity into the tax system, which their 
revenue could easily be replaced by a small increase in other taxes and they are poorly designed to achieve their aim.

115. There has been some discussion of the possibility of excise duties of this type in other OECD countries because of the wish to encourage healthy eating, but most countries have not adopted them. One of the difficulties is in deciding which goods should be taxed. Should the taxes just be based on sugar content or should it reflect fat content, and which sorts of fats? Another issue is how high the tax would have to be in order to have a significant effect on behavior.

116. A particular problem with Iceland's food excises is that they do not systematically reflect the sugar content in the food. In particular, they do not tax the sugar in dairy products. This means that it is still possible for consumers to purchase sugary foods without paying the tax, undermining its purpose. It would be better to have an excise on sugar that would then automatically be built into the price of domestically produced foods that contain sugar, providing an incentive for producers to reduce the sugar content of their products. Imports would be taxed on their sugar content.

\section{Recommendation}

- $\quad$ The excises on foods should either be modified to provide a consistent reflection of sugar (and possibly fat) content or else be abolished, when budgetary pressures subside.

\section{Excises on Alcohol, Fuel and Tobacco}

\section{Issue}

117. The excises on alcohol and tobacco are high by OECD and European standards but generally consistent with the rates in Nordic countries. However, the excise duties on vehicle fuels are low by Nordic standards when converted at market exchange rates. Because of the need to combat climate change and because of the current fiscal situation, this raises the possibility of increasing the excise on motor fuel.

\section{Analysis}

118. The argument in favor of increasing fuel excises is the need to combat climate change and the fiscal situation. The argument against increasing these excises is that it will increase the consumer price index. In addition, an increased excise duty would probably fall particularly on those in remote rural areas. That is true of almost all countries, including Finland, Norway and Sweden. Nonetheless, the effects on remote areas can be largely offset by using part of any additional revenue as a compensation package to subsidize public transport, particularly in rural areas. 
119. The difference between the taxes on fuel in Iceland and other Nordic countries is reduced if the comparison is made at purchasing power parity (PPP) exchange rates rather than the usual international comparison at market exchange rates (Table 12). However, the difference in results from the two comparison methods will possibly diminish over the next few years owing to inflation differentials. Also, it is not clear that purchasing power parity comparisons are better than those at market rates. Nonetheless, it might be prudent to take a gradual approach to the raising of these taxes. If the levels of taxation on motor fuels were increased to remove half of the (market rate) difference between Icelandic and Norwegian levels, approximately 0.35 percent of GDP would be raised as additional revenue, of which 0.1 percent could be used to subsidize public transport.

Table 12. Comparison of Fuel Taxes

(In ISK per liter, rates converted using the stated exchange rates)

\begin{tabular}{|c|c|c|c|c|c|c|}
\hline & \multicolumn{3}{|c|}{ Petrol tax } & \multicolumn{3}{|c|}{$\begin{array}{l}\text { Diesel } \\
\operatorname{tax}\end{array}$} \\
\hline & $\begin{array}{l}\text { Current } \\
\text { market } \\
\text { exchange } \\
\text { rate }\end{array}$ & $\begin{array}{l}\text { Purchasing } \\
\text { Power } \\
\text { Parity, 2009 }\end{array}$ & $\begin{array}{c}\text { Purchasing } \\
\text { Power Parity, } \\
2012 \text { (prj.) }\end{array}$ & $\begin{array}{c}\text { Current } \\
\text { market } \\
\text { exchange } \\
\text { rate }\end{array}$ & $\begin{array}{l}\text { Purchasing } \\
\text { Power } \\
\text { Parity, } \\
2009\end{array}$ & $\begin{array}{c}\text { Purchasing } \\
\text { Power Parity, } \\
2012 \text { (prj.) }\end{array}$ \\
\hline Iceland & 62.61 & 62.61 & 62.61 & 55.67 & 55.67 & 55.67 \\
\hline Denmark & 95.47 & 57.75 & 64.62 & 71.71 & 43.38 & 48.54 \\
\hline Finland & 125.40 & 90.09 & 103.81 & 72.88 & 52.36 & 60.33 \\
\hline Norway & 97.68 & 57.98 & 61.50 & 76.79 & 45.58 & 48.35 \\
\hline Sweden & 97.68 & 72.88 & 81.90 & 76.78 & 57.29 & 64.38 \\
\hline Average excluding Iceland & 104.06 & 69.68 & 77.96 & 74.54 & 49.65 & 55.40 \\
\hline
\end{tabular}

Sources: National sources, IMF WEO, and staff calculations.

\section{Recommendation}

- If the authorities wish to mobilize additional revenue, the excise duty on vehicle fuels could be raised towards Norwegian levels when the carbon tax (see below) is taken into account. This should be accompanied by increased subsidies to public transport. 


\section{E. Taxes on Motor Vehicles}

\section{Issue}

120. The government is considering changes to the excise duty on car imports and the annual fee for car use, moving from rates based on the engine size (excise duty) and weight (annual fee) of the vehicle to rates based on their carbon emissions, on a revenue-neutral basis. The changes would also extend these taxes to pickup trucks, but with a reduced rate for flexi-fuel vehicles.

\section{Analysis}

121. The current rates of these taxes are comparable to other Nordic countries, so there is no reason to change the general level of collections. However, the EU is moving towards differentiating the rates of tax according to carbon emissions in order to encourage consumers to purchase more fuel efficient vehicles, something that is needed in order to mitigate the risk of climate change. The plans in Iceland are therefore both sensible and in line with European trends.

122. Currently pick-up trucks are exempt from these taxes. However, this exemption is hard to justify in general (as it is distortionary) and is even harder to justify when the rates embody an environmental objective. There is no justification for exempting pick-up trucks and their potential purchasers from the incentive to purchase fuel efficient cars.

\section{Recommendation}

- $\quad$ The proposed changes to the excise duties are in the right direction and they would be more effective if pick-up trucks were be included.

\section{F. Resource and Environmental Taxes}

Issue

123. Are the new resource taxes on electricity and water as well as the new carbon tax improvements to the tax system?

\section{Analysis}

124. Natural resources produce rent for their users, and it is a waste of such community resources to allow these rents to be untaxed. The move towards introducing these resource taxes is, therefore, to be welcomed. It is difficult to tell whether they have been introduced at the correct rates but it is probable that, given their low level, the rates could be increased without exhausting the rents. Further analysis is required before a suitable rate for the longterm can be properly decided. 
125. The introduction of a carbon tax on the carbon content of fossil fuels is also to be welcomed, partly because carbon content is a rational basis for determining taxes on fuels and partly because it increases the taxation of vehicle fuels, which is currently rather low (see above). It is also good that all consumers of the fuels, and not just road users, are covered by the tax.

126. However, the tax could be improved by applying the same tax to industrial users of carbon, as efficiency requires that all producers of carbon dioxide should be taxed at the same rate. Also, the rate of tax, currently set at about half the permit price in the EU Emission Trading System (ETS) for carbon permits, should be raised to equal the European permit price as that will be the cost that Iceland will face for carbon emissions in the longer term.

\section{Recommendation}

- $\quad$ These taxes are welcome from the environmental and economic efficiency angles. However, there is probably considerable scope for increasing the resource taxes without causing any distortions and the appropriate level requires further analysis. Also, the carbon tax should apply to all carbon consumers and its rate should be increased to equal the ETS price. 


\section{APPENDIX: SUMMARY OF RECOMMENDATIONS}

\section{CIT and debt forgiveness}

- Introduce the necessary provisions in the Income Tax Act that make the profit determined according to the financial statement the basis for the taxable profit, allowing only those deviations explicitly provided for in the Income Tax Act.

- $\quad$ The income tax should treat as ordinary profits capital gains and losses on business assets that are recognized in accordance with financial accounting rules. Consequently, income arising from debt forgiveness should be considered taxable income but would be offset against these losses. Income in excess of losses, if any, should be taxed.

- A one-time transitory mechanism should be adopted to allow the tax recognition of capital losses incurred during the crisis up to an amount commensurate to the income arising from debt forgiveness. This could be closely monitored and authorized by the tax administration on a case by case basis in accordance with publicly announced rules. For individuals, the tax authority should exempt income from mortgage debt forgiveness up to the point where the debt is equal to the market value of the property reduced by reasonable foreclosure and sale costs to the lender.

- A thin capitalization provision based on either the debt-to-equity ratio or the earnings test should be introduced. An earnings test based on EBITDA is possibly preferable due to its simplicity and lower potential for avoidance.

- $\quad$ The 15 percent withholding tax on interest payments to residents in treaty countries should be waived or reduced (as provided by the treaty) at source, using precertification of residence. Consider disallowing the deduction of interest payments made to residents in a low tax country.

- The participation deduction should be reformed into a participation exemption, bringing the tax treatment of intercompany dividends in line with other European countries. Add to the current threshold of 10 percent shareholding a second (alternative) threshold in the form of a fixed amount of investment - calibrated to the specific situation in Iceland.

- Investment incentives under consideration should not be adopted. If this is not feasible, the annual turnover requirement should be increased drastically in order to cover only very large investments.

- $\quad$ Maintain the current 10-year period of loss carry forward. 


\section{PIT and direct taxes on individuals}

- $\quad$ Retain the dual income tax structure rather than switching to a comprehensive income tax.

- $\quad$ Allocate revenue in closely held businesses according to either the net or gross assets methods. The gross assets method would be preferable as it offers less opportunity for tax arbitrage. This income splitting regime should apply to both closely held corporations and partnerships.

- If needed, to increase progressivity and raise revenue, introduce a single 10 percent surcharge on incomes above ISK 4.5 million. Do not raise the basic tax credit or initial tax rate.

- $\quad$ As the economy recovers, phase out mortgage interest deduction over time for all but low-income, first-time home buyers.

- $\quad$ Reduce social security tax rate as budgetary pressures decline.

- $\quad$ Simplify net wealth tax by allowing the use of financial accounting valuations.

\section{Corporate and individual capital income taxation}

- If additional revenue is needed, increase both CIT and capital income tax rates to 20 percent. Over the medium term, consider reducing the double taxation of dividends and capital gains by introducing a modified ACE.

VAT

- $\quad$ Move to a single rate of VAT, using between a quarter and a third of the additional revenue for a compensation package for those on low incomes that will improve overall progressivity. Ideally, this would be achieved in a single step. However, if necessary, it could be staged, with a first step that raises the reduced rate back to 14 percent and restricts it to food. Also, remove VAT exemptions that are not included in the EU VAT Directive, with a compensatory subsidy to public transport.

- $\quad$ Provide reimbursement for input VAT to local government services that could be outsourced. In the current fiscal situation it is best to limit the reimbursements to those services. 


\section{Other taxes}

- If the authorities wish to mobilize additional revenue, the excise duty on vehicle fuels could be raised towards Norwegian levels (including the carbon tax). A proportion of the extra revenue could be used for compensatory subsidies to public transport.

- Increases in the rates of recurrent property taxes, particularly on residential property, could be considered as the housing market and incomes recover.

- $\quad$ As budgetary pressures subside and unemployment declines, reduce social security tax rate.

- $\quad$ The stamp taxes should be reduced or eliminated when the fiscal situation allows it.

- $\quad$ The excises on foods should either be modified to provide a consistent reflection of sugar (and possibly fat) content or else be abolished, possibly when budgetary pressures subside.

- $\quad$ There is probably considerable scope for increasing the resource taxes without causing any distortions although the appropriate level requires further analysis. Also, the carbon tax should apply to all carbon consumers and its rate should be increased to equal the ETS price.

- The proposed changes to the excise duties on motor vehicles are in the right direction and they would be more effective if pick-up trucks were included. 